Florida International University FIU Digital Commons

6-14-2013

\title{
Effects of Multiple Ecological Drivers on Recruitment and Succession of Coral Reef Macroalgal Communities
}

Alain Duran

adura023@fiu.edu

DOI: $10.25148 /$ etd.FI13080520

Follow this and additional works at: https://digitalcommons.fiu.edu/etd

Part of the Biodiversity Commons, Biology Commons, Botany Commons, Marine Biology

Commons, Other Ecology and Evolutionary Biology Commons, Plant Biology Commons, and the Terrestrial and Aquatic Ecology Commons

\section{Recommended Citation}

Duran, Alain, "Effects of Multiple Ecological Drivers on Recruitment and Succession of Coral Reef Macroalgal Communities" (2013). FIU Electronic Theses and Dissertations. 905.

https://digitalcommons.fiu.edu/etd/905 


\title{
FLORIDA INTERNATIONAL UNIVERSITY
}

Miami, Florida

\section{EFFECTS OF MULTIPLE ECOLOGICAL DRIVERS ON RECRUITMENT AND SUCCESSION OF CORAL REEF MACROALGAL COMMUNITIES}

\author{
A thesis submitted in partial fulfillment of the \\ requirements for the degree \\ of \\ MASTER OF SCIENCE \\ in \\ BIOLOGY \\ by \\ Alain Duran
}

2013 
To: Dean Kenneth Furton

College of Arts and Sciences

This thesis, written by Alain Duran, and entitled Effects of Multiple Ecological Drivers on Recruitment and Succession of Coral Reef Macroalgal Communities, having been approved in respect to style and intellectual content, is referred to you for judgment.

We have read this thesis and recommend that it be approved.

Craig Layman

Deron Burkepile, Co-Major Professor

Ligia Collado-Vides, Co-Major Professor

Date of Defense: June 14, 2013

The thesis of Alain Duran is approved.

Dean Kenneth Furton
College of Arts and Sciences

Dean Lakshmi N. Reddi University Graduate School

Florida International University, 2013 


\section{DEDICATION}

Dedicated to my grandpa, a successful family man who never lost his sense of humor, to my son Andy, I hope you see this work as an inspiration for your future professional development, to Mayle, thank you for being always there, and to my mother, who always encourages me to pursue my goals. 


\section{ACKNOLWEDGMENTS}

I would like to thank Ligia Collado-Vides for having opened the doors for me to reencounter the marine science world. Likewise, I would like to thank Deron Burkepile for trusting and giving me the opportunity of developing my professional career. Without, their guidance and constant help this thesis would not have been possible. Also, I like to thank to Dr. Craig Layman for being part of my committee and for supporting me at all times. In addition, a thank you to all members of both Marine Ecology Lab and Marine Macroalgae Research Lab, including their amazing grads and undergrads, for helping every time I needed. I thank Dr. Lacey (Z) and Dr. Dení Rodriguez for their very important contributions to this work and my personal professional formation. Also, I would like to express my appreciation to FIU biology department (Helen, Eliana, Ileana, and many others) and its educators, particularly those who directly taught me how to do science and inspired me with their actions, Dr. Koptur and Dr. Fourqurean. Thank

you very much Mr. Sanchez for teaching me how to teach and communicate. The last but not the least, thank you to my family and friends for helping and encouraging me. 


\title{
ABSTRACT OF THE THESIS \\ EFFECTS OF MULTIPLE ECOLOGICAL DRIVERS ON RECRUITMENT AND \\ SUCCESSION OF CORAL REEF MACROALGAL COMMUNITIES
}

\author{
by \\ Alain Duran \\ Florida International University, 2013 \\ Miami, Florida \\ Professor Ligia Collado-Vides, Co-Major Professor \\ Professor Deron Burkepile, Co-Major Professor
}

The study evaluated the effects of herbivory pressure, nutrient availability and potential propagule supply on recruitment and succession of coral reef macroalgal communities. Recruitment and succession tiles were placed in a nutrient-herbivory factorial experiment and macroalgal abundances were evaluated through time. Proportional abundances of macroalgal form-functional groups on recruitment and succession tiles were similar to field established communities within treatments, evidencing possible effects of adult macroalgae as propagule supply. Macroalgal abundance of recruitment tiles increased with nutrient loading and herbivory reduction combined whereas on succession tiles nutrient loading increased abundance of articulated-calcareous only when herbivores were excluded. Macroalgal field established communities were only affected by herbivory reduction. 


\section{TABLE OF CONTENTS}

CHAPTER

PAGE

1. BACKGROUND........................................................ 1

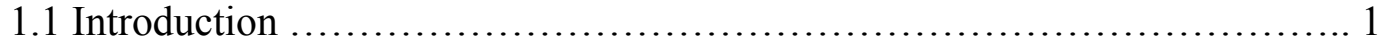

1.2 Top-down drivers of coral reef macroalgal community...................... 2

1.3 Bottom-up drivers of coral reef macroalgal community.................... 4

1.4 Propagule supply and recruitment of macroalgae in coral reefs................ 7

1.5 Succession of coral reef macroalgal communities........................ 10

References.......................................................... 13

2. RECRUITMENT AND SUCCESSION OF CORAL REEF MACROALGAL COMMUNITIES UNDER DIFFERENT ECOLOGICAL DRIVERS ................. 23

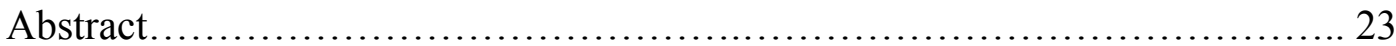

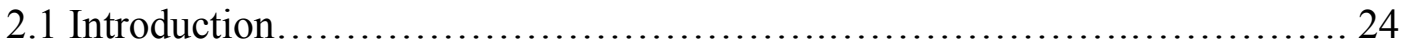

2.2 Materials and Methods..................................................... 29

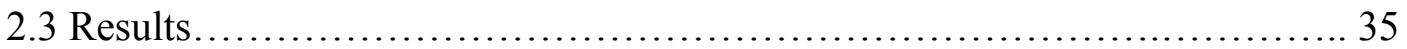

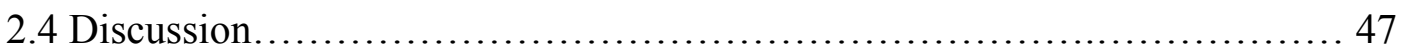

References.......................................................... 54

3. CONCLUSIONS, IMPLICATIONS AND FUTURE DIRECTIONS ............... 62

Conclusions, implications and future directions............................ 62

References........................................................... 66

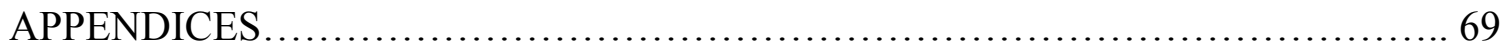




\section{LIST OF FIGURES}

FIGURE

PAGE

1. Conceptual model.................................................... 13

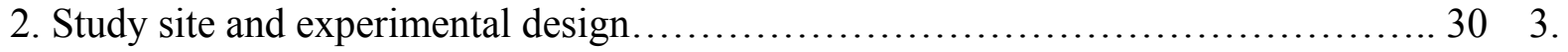

Total and herbivorous fish biomass and density ............................ 35

Percent cover of field established macroalgal communities....................... 37

5. Average number of algal species found on tiles by phylum in each set............ 40

6. Total percent cover of macroalgal by treatment among sets of recruitment tiles...... 41

7. Non-metric Multidimensional Scaling analysis using abundance of all species of algae on recruitment tiles by set.................................................. 42

8. Non-metric Multidimensional Scaling analysis of macroalgal species on recruitment

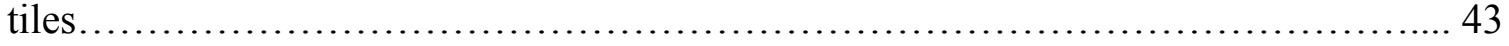

9. Form-functional group macroalgal abundance of permanent tiles.................. 44

10. Graphical representation of macroalgal on permanent tiles by treatment............ 46

11. Non-metric Multidimensional Scaling analysis of form-functional groups by treatment on permanent tiles in January and June................................ 46

12. Schematic representation of magnitude effects of coral reef major drivers throughout macroalgal succession........................................................ 51 


\section{CHAPTER 1 - BACKGROUND}

\subsection{Introduction}

Coral reefs provide a wide variety of functional values such as dissipation of wave energy, biogeochemical cycling, and nursery habitats for multiple species (Harborne et al., 2006). Furthermore, human communities living adjacent to coral reefs receive goods and services such as food, recreation, and tourism income that place the value of coral reefs at approximately $\$ 29.8$ billion per year (Cesar et al., 2003). Despite the economic and ecological importance of coral reef ecosystems, they are threatened by local anthropogenic impacts (e.g., overfishing, eutrophication, habitat destruction among others) that intensify the effects of global stressors such as ocean acidification and thermal stress (Hoegh-Guldberg et al., 2007). Consequently, coral reefs worldwide, particularly in the Caribbean, have suffered long-term degradation caused by the decline of large carnivores and herbivores and the loss of overall coral cover (Pandolfi et al., 2003). In the last three decades coral cover in some places of the Caribbean has been reduced to ten percent or less (Gardner et al., 2003) resulting in a phase shift from a coral-dominated to a coral-depauperate state (Hughes, 1994; Roger and Miller, 2006; Mumby, 2009). Further, there are several causes of coral cover declined such as coral diseases, coral bleaching events, out-break of coral-eating organisms, and storm damage (Goreau et al., 1998; Eakin et al., 2010; Kayal et al., 2012).

As a consequence of reduced coral cover, new available space has been created which can be colonized by macroalgal propagules, leading to increased abundance of macroalgae (Diaz-Pulido and McCook, 2002; Mumby and Steneck, 2008). Once macroalgal propagules have settled, different species or form-functional groups of macroalgae can become dominant throughout time following different successional patterns (Sammarco, 1983; Hixon and Bostroff, 
1996; Diaz-Pulido and McCook, 2002). Recruitment of algae species and post-settlement succession of coral reef macroalgae communities are both shaped by different herbivore groups such as farmers (Pomancentridae), fish grazers (Acanthuridae and Scaridae) and sea-urchin grazers (Carpenter, 1986; Hixon and Brostoff, 1996; McClanahan, 1997). Indeed, some authors have suggested loss of herbivory (top-down driver) as a major cause of increasing macroalgal abundance on coral reefs, but nutrient enrichment (bottom-up) can amplify its effects (Burkepile and Hay, 2006; Walsh, 2011). Conversely, it has been proposed that nutrient loading is the primary factor regulating biomass and diversity of reef macroalgal communities (Lapointe et al. 1997; Lapointe et al., 2004). However, top-down and bottom-up forces likely interact with one another to shape algal communities (Burkepile and Hay 2006). Little is known about how macroalgal propagule supply interacts with nutrient loading and herbivory to shape the recruitment and succession of coral reef macroalgal communities (De Ruyter and Breeman, 1987; Walters et al., 2002).

\subsection{Top-down drivers of coral reef macroalgal community}

Several vertebrate and invertebrate herbivores feed on coral reef macroalgae, functioning as important top-down controls (Hay, 1984; Lewis, 1986; Edmunds and Carpenter, 2001; Burkepile and Hay, 2010; Butler and Mojica, 2012). Coral reef herbivores can be classified by body size, foraging range, grazing frequency, and impact on benthic communities (Steneck, 1983). Carpenter (1986) grouped reef herbivores into three categories: micro-herbivores (restricted mobility and small grazing range such as amphipods, tanaids and gastropods), intermediate size herbivores (crabs, sea urchins and blenids), and foragers (larger organisms with higher grazing rates, such as fish including parrotfish (Scaridae), surgeonfish (Acanthuridae) and chubs (Kyphosidae). Damselfish (Pomacentridae) belong to the intermediate sized herbivore 
group as they have limited territories and remove small amounts of algal biomass. However, they are unique since their distinctive territorial behavior affects consumption rates of other grazers (Jones et al., 2006). Because of their foraging habits and different effects on algal communities as compared to other herbivores, they are often referred to as farmers (Ceccarelli et al. 2005). Despite a high diversity of herbivores, sea urchins and herbivorous fish often remove most of the algal biomass from coral reefs (Solandt and Campbell, 2001; McClanahan et al., 2002; Bellwood, 2003; Steiner and Williams, 2006; Blanco et al., 2011). For instance, the functional importance of the long-spined sea urchin (Diadema antillarum) as a top-down driver was well studied before its massive die-off in 1983-84, which resulted in a dramatic increase of macroalgae on many Caribbean coral reefs (Sammarco, 1982; Carpenter, 1986, Lessios et al., 1984). Even though the mass mortality of $D$. antillarum influenced the present-day phase shift from coral to macroalgae domination in some areas of the Caribbean (Hughes, 1994; Mumby et al., 2006), it has been shown that the loss of herbivorous fishes could have major impact (Hay, 1984).

Anatomical, morphological, and physiological traits allow different species of parrotfish (Scaridae) and surgeonfish (Acanthuridae) to remove multiple types of macroalgae, such as small and soft filamentous algae, upright, leathery macroalgae, and crustose macroalgae (Tilghman et al., 2001; Crossman et al., 2005). Nonetheless, herbivore consumption rates are affected by macroalgal morphology, specific chemical defenses and tissue nutrient content, resulting in selective grazing by herbivores (Targett et al., 1986; Duffy and Hay, 1994; Schupp and Paul, 1994; Hay, 1997; Hoey and Bellwood, 2011) which results in herbivore-specific feeding preferences (Hay et al., 1987). For instance, Burkepile and Hay (2010) reported speciesspecific grazing rates and preferences among three common Caribbean herbivorous fish; 
herbivory pressure by Acanthurus bahianus (ocean surgeonfish) and Scarus taeniopterus (princess parrotfish) kept the macroalgae community at a short turf and crustose coralline algae (CCA) level considered early successional stages. In contrast, foraging activity of Sparisoma aurofrenatum (redband parrotfish) resulted in taller macroalgae community, late successional stages, very similar to caged experimental treatments. Thus, coral reef macroalgae communities are controlled by multiple herbivorous fishes capable of limiting abundance of macroalgae and promoting growth of CCA (Burkepile and Hay, 2009; Smith et al., 2010).

\subsection{Bottom-up drivers of coral reef macroalgal community}

Macroalgal primary production is directly related to nutrient and light availability (Lüning, 1990). In shallow, relatively oligotrophic tropical regions such as the Caribbean, nutrient availability can often limit macroalgal productivity (Lapointe et al., 1997). Although nutrients are recognized to be a major factor determining abundance and diversity of certain macroalgal functional groups, it is still unclear with regards to their role in promoting increases of algal abundance on coral reefs (McClanahan et al., 2004; Burkepile and Hay, 2006; McClanahan et al., 2007). Availability of main macronutrients, nitrogen $(\mathrm{N})$ and phosphorus (P), and their roles in driving macroalgal growth are focus of a strong debate among coral reef ecologists (Hughes, 1994; Lapointe et al. 1997; Lapointe et al., 1999; Hughes et al., 1999).

Dissolved inorganic nitrogen (DIN), which includes $\mathrm{NH}_{4}^{+}, \mathrm{NO}_{3}^{-}, \mathrm{NO}_{2}^{-}$; and soluble reactive phosphorus (SRP) are limiting factors of primary production used to evaluate nutrient availability in marine environments (Smith, 1984; Lapointe et al., 2005). Even though some nutrient thresholds have been proposed to predict algal domination on coral reefs, DIN $1.0 \mu \mathrm{M}$ and SRP $0.1 \mu \mathrm{M}$ (Lapointe et al. 1993; Lapointe et al., 2005) several studies on this topic have not generally supported these concrete thresholds for predicting macroalgal dominance (Lapointe 
et al., 1993; Hughes, 1994; Lapointe et al., 1997; Hughes et al., 1999; Lapointe et al., 1999; Lapointe et al., 2005). It is possible that some factors such as species-specific differences in nutrient uptake rate and physiological state of individuals (whether or not individuals are nutrient limited) would limit the potential for establishing nutrient thresholds that could lead to increase abundance of coral reef macroalgae (Fong et al., 2001; Dailer et al., 2012).

Several conceptual models have been put forth to explain the effect and magnitude of major ecological drivers responsible for controlling abundance of coral reef macroalgae (e.g., herbivory and nutrients; Littler and Littler, 1984; Steneck and Dethier, 1994; Littler et al., 2006). The Relative Dominance Model (RDM) was proposed by Littler and Littler (1984) where four groups of benthic reef organisms are predicted to dominate depending upon bottom-up (nutrient levels) and top-down (herbivory activity) ecological controlling forces. According to Littler and Littler (1984) coral reefs with low nutrient levels and low herbivory tend to have higher abundance of filamentous algae whereas high nutrient levels and high herbivores activity favors dominance of coralline algae. Their conceptual model also predicts that a combination of low nutrient levels and high herbivory facilitates coral dominance and contrarily high nutrient levels and low herbivore activity enhances abundance of fleshy algae.

On the basis of Grimes's model (1977) and Littler and Littler's model (1984), Steneck and Dethier (1994) proposed a conceptual model combining productivity potential of different macroalgal form-functional groups and disturbance potential, defined as intensity and frequency of grazing. The model expects higher macroalgal biomass at low disturbance and high productivity potential levels while lower macroalgal biomass at low productivity and high disturbance potential levels (Steneck and Dethier, 1994). Importantly, Steneck and Dethier's model included seven macroalgal form-functional groups having leathery (e.g., Sargassum spp.) 
and articulated calcareous (e.g., Amphiroa spp.) the highest biomass when there is a combination of low disturbance and high productivity potential levels. The Relative Dominance Model was modified in 2006 by Littler et al., by integrating coral reef resiliency and human impact concepts and modifying dominant groups under different levels of both grazing activity and nutrient availability. The new proposed model predicts dominance of coral and crustose coralline algae (CCA) when combining low nutrient and high grazing activity levels suggesting that lower human impact results in more resilient coral reefs.

Factorial experiments testing the above mentioned conceptual models by manipulating nutrient availability and herbivory level have demonstrated that nutrient loading can affect coral reef macroalgae abundance only when herbivores are absent (Burkepile and Hay, 2006, 2009; Sotka and Hay, 2009). Additionally, it has been revealed that herbivore exclusion could increase reef macroalgae cover faster (less than one month) than nutrient loading (Smith et al., 2010). Moreover, a noticeable response (increased abundance) of coral reef macroalgae to nutrient enrichment could be evident only after approximately three to four months (Smith et al., 2010). Furthermore, it has been shown that grazing intensity could be modified by nutrient availability where enriched algae are preferably consumed by herbivorous fish (Boyer et al., 2004; Burkepile and Hay, 2009). In summary, variations in magnitude effect of nutrient availability depend on the context (e.g., herbivory pressure level, macroalgal species composition) and specific study time scale.

\subsection{Propagule supply and recruitment of macroalgae in coral reefs}

Recruitment in marine environments, defined as addition of new individuals to populations, is a determinant process structuring open populations (Caley et al., 1996; Robersson and Kaufman, 1998). Furthermore, recruitment rates of marine organisms are determined by the 
number of propagules (marine plants) and larvae (marine animal) available as well as natural disturbances and oceanographic processes such winds and currents (Reed et al., 1988; Caley et al., 1996; Wilson and Meekan, 2001; Clark and Johnston, 2005). In that sense, some ecological studies of coral reef fishes have shown that fish recruitment is directly affected by number of larvae (larval supply) and other factors such as microhabitat characteristics and currents (Milicich et al., 1992; Sale, 2004; Grorud-Colvert and Sponaugle, 2009). Likewise, Stoner et al. (1996) described substantial differences in larval density (number of veliger) of Queen Conch (Strombus gigas) between two separated populations caused by differential abundance of reproductive adults and consequently larval supply. In the case of marine macroalgae, propagule supply and dispersal distance have been also proposed to play an important role on population recruitment but few studies have focused on coral reef macroalgae (Kendrick and Walker, 1991; Stiger and Payri, 1999).

Macroalgae can reproduce either sexually or asexually resulting in a large production of propagules, such as zygotes, parthenogenetic gametes, spores and fragments that are released to the marine environment. However, reproduction events are triggered by several environmental factors such as lunar cycle, photoperiod, water temperature, and natural disturbances (Luning, 1990), which in many species may explain marked seasonality. For instance, Andersson et al. (1994) showed a circadian (18:00 to 22:00 h) and fortnightly rhythm for egg release during the reproductive season of Fucus vesiculus in the Baltic Sea. Also, Hay and Norris (1984) found that six sympatric species of the red algae within the genus Gracilaria exhibited an increase in the percentage of reproductive plants following the onset of the turbid dry-season in late November. Clifton (2008) suggested that earlier reproductive period of some bryopsidales species (Phylum Chlorophyta) in Panama compared to Florida Keys could be a consequence of warmer water 
occurring earlier in Panamanian coastal zone. Additionally, species of Enteromorpha recruited abundantly from overwintering propagules in March-April and dominated areas with propagule banks in Baltic rocky shores (Worm et al., 2001). Santos and Duarte (1996) found a spore peak production of Gelididum sesquipedale $\left(10.4 \times 10^{6}\right.$ spores $/ \mathrm{m}^{2}$ and $4.9 \times 10^{5}$ spores $/ \mathrm{m}^{2}$ of tetrasporophyte and carposporophyte respectively) in March at the coastal area of Portugal. In China, Sargassum thunberguii shows a reproductive season from spring to early summer (MayJune) where the number of germlings per $\mathrm{kg}$ of adult reaches about $1.2 \times 10^{5}$ quantified from natural populations (Zhang et al., 2012). Noticeably, the number of macroalgae propagules in marine systems is high and varied with species-specific reproductive periods. Regardless of the seasonality of reproduction, the role of adult macroalgal assemblage structure as propagule supply is an important factor on determining macroalgal recruitment (Lotze et al., 2000). Indeed, establishment of macroalgal assemblages is affected by the number of mature individuals as well as adult fertility affecting propagule supply (Stiger and Payri, 1999; Bellgrove et al., 2004).

After propagules have been released from the parent plant, they must settle, attach, and become established (Fletcher and Callow, 1992). Environmental factors such as water flow and viscosity can influence propagule sinking speed and subsequent establishment (Chartes et al., 1973; Okuda and Neushul, 1981; Granhag et al., 2004). Further, temperature, salinity and surface roughness affect the ability of propagules to attach and establish on the substrate (Callow et al., 1997; Maggs and Callow, 2002). Diaz-Pulido and McCook (2004) found density of settlement significantly higher on rough surfaces compared to smooth surfaces for reef species of order Fucales (mostly Sargassum spp.) and Lobophora variegata. Moreover, Ericksson and Johansson (2003) concluded that sediment, particularly organic sedimentation, had a negative effect on macroalgal recruitment. 
Along with number of propagules, recruitment success and consequently development of macroalgal community structure are determined by propagule dispersal. Further, it has been proposed that macroalgal dispersal distance is among the shortest for marine organisms with over $60 \%$ of propagules being retained within less than one $\mathrm{km}$ from the parent plant (Kinlan and Gaines, 2003; Kinlan et al., 2005). However, a high variation of dispersal distance along with type and size of propagule can be found among algal species. For instance, Reed et al (1988) described equal densities of filamentous brown algae recruits from the parent thalli up to $500 \mathrm{~m}$ away. Conversely, Kendrick and Walker (1991) found that 96\% propagules of Sargassum spinuligerum settled within 0.25 meter from the parent thalli. Additionally, propagules of Macrocystis sp. could successfully be recruited over $3 \mathrm{~km}$ from parent plants (Reed et al., 2004). Hence, species-specific variations in dispersal distances could be a function of parent height, propagule size and abiotic factors with currents being especially important (Okuda and Neushul, 1981; Norton, 1992; Gaylord et al., 2006). Thus, composition of local macroalgal community may strongly determine the abundance and species identity of macroalgal propagules and ultimately recruitment patterns on coral reefs

\subsection{Succession of coral reef macroalgal communities}

After propagules have established, different species of macroalgae can become dominant at different times following successional dynamics (Hixon and Brostoff, 1996; Diaz-Pulido and McCook, 2002). Several successional patterns have been described for coral reef macroalgae communities depending upon abundance and type of herbivores, as well as substrate type and competition between algae and other benthic organisms for space (McClanahan, 1997; DiazPulido and McCook, 2002). Sammarco (1983) compared the effect of territorial damselfish behavior and large herbivorous fish (parrotfish and surgeonfish) on algal community 
composition using four treatments (caged, shaded, territory and open). After three months, plates in all four treatments were covered by turf algae ( $>67 \%$ cover). But in open areas, naturally grazed by fish, turf algae decreased after 11 months resulting in bare substrate and endolithic algae covering $40 \%$ and $50 \%$ of plots respectively. Interestingly, macroalgal diversity was higher within damselfish territories compared to exclosure treatments (Sammarco, 1983). Additionally, Carpenter (1986) evaluated the impact of different herbivore groups on succession of macroalgal communities. One month after initiation of the experiment, all plates were comprised of approximately $80 \%$ turf algae. After nine months, macroalgae (height $>1 \mathrm{~cm}$ ) covered over $50 \%$ of the tiles within cages where urchins (primarily D. antillarum) and herbivorous fishes were excluded. When only fishes and microherbivores grazed the plates, macroalgae turf (height $<1$ $\mathrm{cm}$ ) had higher biomass and lower diversity (dominated by Sphacelaria tribuloides), whereas in treatments only grazed by urchins and microherbivores macroalgae biomass was lower and turf algae encompassed 20-25 species (Carpenter, 1986). Furthermore, Hixon and Brostroff (1996) studied the effect of herbivory on the rate and trajectory of coral reef macroalgae succession. They compared development rate and diversity of reef macroalgal communities under three treatments: damselfish territory (Stegastes fasciolatus), grazed areas (open to parrotfish and surgeonfish) and caged areas (herbivore exclusion). Results demonstrated that, compared to open treatments, damselfish decelerated (slowed) succession by maintaining the community at earlysuccessional stages dominated by green and brown filamentous algae for over 230 days. In contrast, in open areas the trajectory of macroalgal succession was different as the earlysuccessional stage was quickly replaced by different groups of macroalgae such as crustose and prostrate algae (Hixon and Bostroff, 1996). Thus, there are evidences of herbivory as a significant driver of coral reef macroalgal succession. Indeed, abundance and diversity of 
macroalgae communities at different successional stages are strongly driven by intensity and frequency of grazing (Burkepile and Hay, 2010).

In conclusion, recruitment and post-settlement succession of coral reef macroalgae are driven by a wide variety of ecological factors including the number and species-specific type of arriving propagules, type and availability of substrate and grazing pressure of different herbivores (Hixon and Bostroff, 1996; McClanahan, 1997; Diaz-Pulido, 2002, 2003; Burkepile and Hay, 2010). However, there remains a lack of information regarding the consequences of their combined interactions. Therefore, my research question is: How does seasonality affect recruitment and post-settlement succession of coral reef macroalgal communities under different levels of nutrient availability and herbivory?

There are multiple studies showing nutrient enrichment, eutrophication, as major cause increasing abundance of opportunistic, fast-growing macroalgal species such as Chaetomorpha spp. Ulva spp., Codium spp. Enteropmorpha spp. Cladophora spp. (Lapointe et al., 1993; Lapointe et al., 1997; McClanahan et al., 2004; Smith et al., 2005). However, when considering major drivers of frondose, fleshy macroalgal species, the primacy of nutrient enrichment is still under debate (Hughes, 1994; Hughes et al., 1999; McClahanhan et al., 2004). I hypothesized that nutrient enrichment will increase (positive effect in conceptual model, Figure 1) percent cover of opportunistic early successional species whereas the magnitude of its effect on macroalgal abundance will decrease towards late successional stages. The effect of coral reef herbivorous fishes controlling multiple macroalgal successional stages has been well documented (Carpenter, 1986, Hixon and Bostroff, 1996; Burkepile and Hay, 2010). Therefore, I predicted that intense herbivory will decrease abundance (negative effect in conceptual model, Figure 1) of macroalgae at all successional stages. In addition, potential propagule supply, defined as the abundance of 
adult macroalgae in close proximity to the studied sites, will increase abundance of macroalgae recruits acting as a propagule source (positive effect in conceptual model, Figure 1).

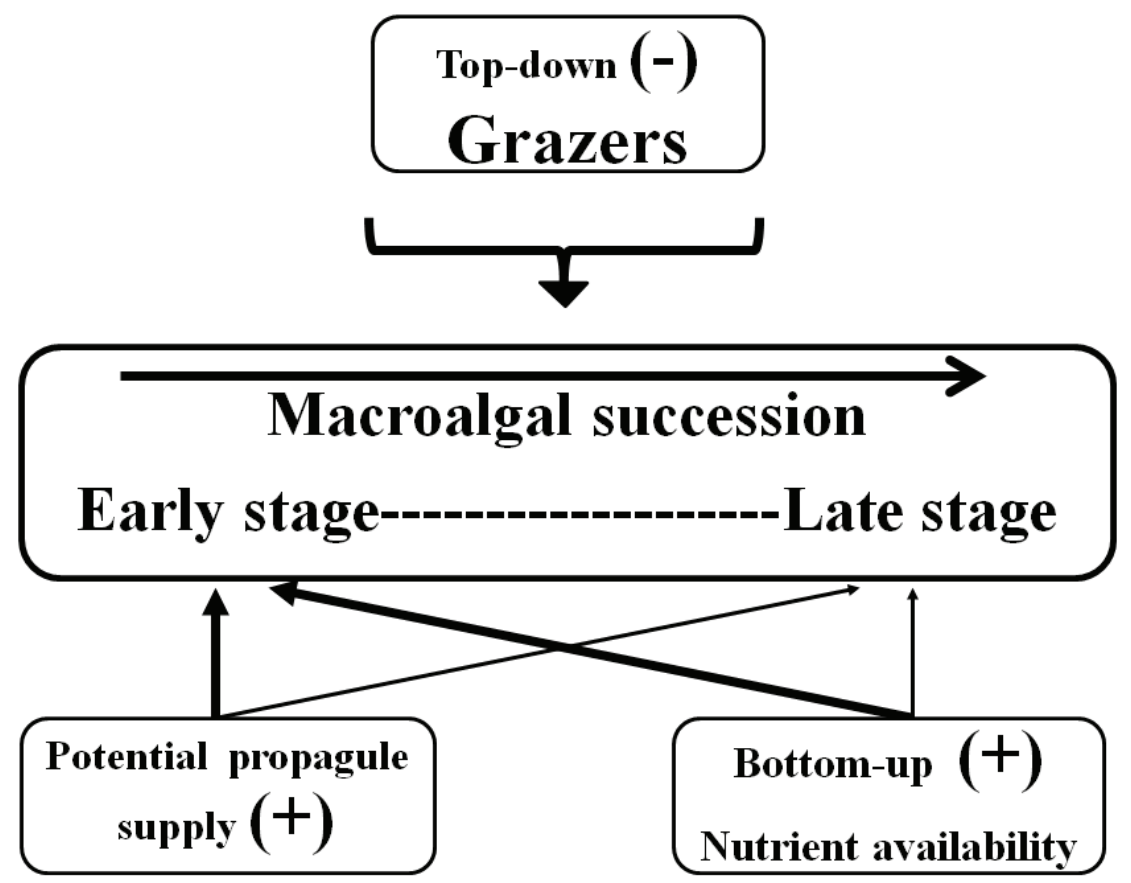

Figure 1. Conceptual model including the ecological factors studied throughout the thesis and their hypothesized effects. (-) symbol indicates overall grazers reducing macroalgal abundance at early and late successional stages; $(+)$ symbols (bottom-up and potential propagule supply) predict increasing of macroalgae cover at early and late successional stages. Effects of nutrient availability and potential propagule supply vary through time with less magnitude effect (thinner arrow) on abundance of macroalgae at late successional stages

\section{References}

Andersson, S., L. Kautsky and A. Kalvas. 1994. Circadian and lunar gamete realease in Fuces vesiculosus in the atidal Baltic Sea. Mar. Ecol.Prog. Ser. 110: 195-201.

Bellgrove, A., M. N. Clayton and G. P. Quinn. 2004. An integrated study of the temporal and spatial variation in the supply of propagules, recruitment and assemblages of intertidal macroalgae on a wave-exposed rocky coast, Victoria, Australia. Journal of experimental marine biology and ecology. 310: 207-225.

Bellwood, D. R. 2003. Origins and escalation of herbivory in fishes: a functional perspective. Paleobiology, 29(1): 71- 83. 
Blanco, F. M., L. C. Alonso, G. G. Sanson and F. P. Amargos. 2011. Influence of Diadema antillarum populations (Echinodermata: Diadematidae) on algal community structure in Jardines de la Reina, Cuba. Rev. Biol. Trop. 59 (3): 1149-1163.

Boyer, K. E., P. Fong, A. R. Armitage and R. A. Cohen. 2004. Elevated nutrient content of tropical macroalgae increases rates of herbivory in coral, seagrass, and mangrove habitats. Coral Reefs. 23: 530-538.

Burkepile, D. E. and M. E. Hay. 2006. Herbivore VS nutrient control of marine primary producers: context-dependent effects. Ecology, 87(12):3128-3139.

Burkepile, D. E. and M. E. Hay. 2009. Nutrient versus herbivore control of macroalgal community development and coral growth on a Caribbean reef. Mar. Ecol. Prog. Ser. 389: 71-84.

Burkepile, D. E. and M. E. Hay. 2010. Impact of herbivore identity on algal succession and coral growth on a Caribbean Reef. PLoS ONE 5(1): e8963. doi:10.1371/journal.pone.0008963

Butler, M. J. and A. M. Mojica. 2012. Herbivory by the Caribbean king crab on coral patch reefs. Mar. Biol. 159: 2697-2706.

Carpenter, R. C.1986. Partitioning herbivory and its effects on coral reef algal communities. Ecol Monogr 56:345-364.

Caley, M. J., M. H. Carr, M. A. Hixon, T. P. Hughes, G. P. Jones and B. A. Menge. 1996. Recruitment and the local dynamics of open marine populations. Annu. Rev. Ecol. Syst. 27: 477:500.

Callow, M. E., J. A. Callow, J. D. Pickett and R. Wetherbee. 1997. Primary adhesion of Enteromorpha (Chlorophyta, Ulvales) propagules: quantitative settlement studies and video microscopy. J. Phycol. 33: 938-947.

Ceccarelli, D. M., G. P. Jones and L. J. McCook. 2005. Effects of territorial damselfish on an algal-dominated coastal coral reef. Coral Reefs. 24: 606-620.

Chartes, A. C., M. Neushul and D. Coon. 1973. The effects of water motion on spore adhesion. Limnology and Oceanography. 18 (6): 884-86.

Clark, G. F. and E. Johnston. 2005. Manipulating larval supply in the field: controlled study of marine invisibility. Mar. Ecol. Prog. Ser. 298: 9-19.

Clifton, K. E. 2008. Spatial patterns of reproductive synchrony by four genera of tropical Green seaweed across a latitudinal gradient in the Caribbean. Proceedings of th $11^{\text {th }}$ International coral Reef Symposium, Ft. Lauderdale, Florida. Session 11: 351-355. 
Cesar, H., L. Burkeand and L. Pet-Soede. 2003. The economics of worldwide coral reef degradation. Cesar Environmental Economics Consulting, Arnhem, and WWFNetherlands, Zeist, The Netherlands: 23 pp.

Crossman, D. J; J. H. Choat. and K. D. Clements. 2005. Nutritional ecology of nominally herbivorous fishes on coral reefs. Mar. Ecol. Prog. Ser. 296: 129-142.

Dailer, L. M., J. E. Smith and C. M. Smith. 2012. Responses of bloom forming and non-bloom forming macroalgae to nutrient enrichment in Hawai'I, USA. Harmful Algae. 17: 111125.

De Ruyter Van Steveninck, E. D. and A. M. Breeman. 1987. Deep water populations of Lobophora variegata (Phaeophyceae) on the coral reef of Curacao: influence of grazing and dispersal on distribution patterns. Mar. Ecol. Prog. Ser. 38:241-250.

Diaz-Pulido, G. and L. J. McCook. 2002. The fate of bleach corals: Patterns and dynamics of algal recruitment. Mar. Ecol. Prog. Ser. 232: 115-128.

Diaz-Pulido, G. and L. J. McCook. 2003. Relative roles of herbivory and nutrients in the recruitment of coral reef seaweeds. Ecology. 84 (8): 2026-2033.

Diaz-Pulido, G. and L. J. McCook. 2004. Effects on live coral, epilithic algal communities and substrate type on algal recruitment. Coral Reefs. 23: 225-233.

Duffy, J. E. and M. E. Hay. 1994. Herbivore resistant to seaweed chemical defense: the roles of mobility and predation risk. Ecology. 75 (5): 1304-1319.

Eakin, C. Mark., J. A. Morgan, S. F. Heron, T. B. Smith, G. Liu, L. Alvarez-Filip, B. Baca, E. Bartels, C. Bastidas, C. Bouchon, M. Brandt, A. W. Bruckner, L. Bunkley-Williams, A. Cameron, B. D. Causey, M. Chiappone, T. R. L. Christensen, M. J. C. Crabbe, O. Day, E. de la Guardia, G. Diaz-Pulido, D. DiResta, D. L. Gil-Agudelo, D. S. Gilliam, R. N. Ginsburg, S. Gore, H. M. Guzman, J. C. Hendee, E. A. Hernandez-Delgado, E. Husain, C. F. G. Jeffrey, Ross J. Jones, E. Jordan-Dahlgren, L. S. Kaufman, D. I. Kline, P. A. Kramer, J. C. Lang, D. Lirman, J. Mallela, C. Manfrino, J-P. Marechal, K. Marks, J. Mihaly, W. J. Miller, E. M. Mueller, E. M. Muller, C. A. O. Toro, H. A. Oxenford, D. Ponce-Taylor14, N. Quinn, K. B. Ritchie, S. Rodriguez, A. Rodriguez-Ramırez, S. Romano, J. F. Samhouri, J. A. Sanchez, G. P. Schmahl, B. V. Shank, W. J. Skirving, S. C. C. Steiner, E. Villamizar, S. M. Walsh, C. Walter9, E. Weil, E. H. Williams, K. W. Roberson and Y. Yusuf. 2010. Caribbean corals in crisis: Record thermal stress, bleaching, and mortality in 2005. PLoS ONE 5(11): e13969. doi:10.1371/journal.pone.0013969.

Edmunds, P. J. and R. C. Carpenter. 2001. Recovery of Diadema antillarum reduces macroalgal cover nad increases abundance of juvenile corals on a Caribbean reef. PNAS. 98 (9):5067-5071. 
Ericksson, B. K. and G. Johansson. 2003. Sedimentation reduces recruitment success of Fucus vesiculosus (Phaephyceae) in the Baltic Sea. European Journal of Phycology. 38 (3): 217 222.

Fletcher, R. L. and M. E. Callow. 1992. The settlement, attachment and establishment of marine algal spores. British Phycological Journal. 27(3): 303-329.

Fong, P., K. Kramer, K. E. Boyer and K. A. Boyle. 2001. Nutrient content of macroalgae with differeing morphologies may indicate sources of nutrients for tropical marine systems. Mar. Ecol. Prog. Ser. 220: 137-152.

Gardner, T. A., I.M. Cote, J. A. Gill, A. Grant and A. R. Watkinson. 2003. Long-term regionwide declines in Caribbean corals. Science. 10.1126:1-5.

Gaylor, B., D. C. Reed, P. T. Raimondi and L. Washburn. 2006. Macroalgal dispersal in coastal environments. Mechanistic insights revealed by theory and experiment. Ecological monograph. 6 (4): 481-502.

Goreau, T. J., J. Cervino, M. Goreau, R. Hayes, M. Hayes, L. Richardson, G. Smith, K. DeMeyer, I. Nagelkerken, J. Garzon-Ferrera, D. Gil, G. Garrison, E. H. Williams, L. Bunkley-Williams, C. Quirolo, K. Patterson, J. W. Porter and K. Porter. 1998. Rapid spread of diseases in Caribbean coral reefs. Rev. Biol. Trop. 46 (5): 157-177.

Granhag, L. M., J. A. Finlay, P. R. Jonsson, J. A. Callow and M. E. Callow. 2004. Roughnessdependent removal of settled spores of green alga Ulva (syn. Enteromorpha) exposed to hydrodynamic forces from a water jet. Biofuling. 20 (2): 117-122.

Grorud-Colvert, K. and S. Sponaugle. 2009. Larval supply and juvenile recruitment of coral reef fishes to marine reserves and non-reserves of upper Florida keys, USA. Mar. Biol. 156: 277-288.

Harborne, A. R., P. J. Mumby, F. Micheli, C. T. Perry, C. P. Dahlgren, K. E. Holmes and D. R. Brumbaugh. 2006. The functional value of Caribbean coral reef, seagrasses and mangrove habitats to ecosystem processes. Advances in marine biology. 50: 1-189.

Hay, M. 1984. Patterns of fish and urchin grazing on Caribbean coral reefs: are previous results typical? Ecology. 65 (2): 446-454.

Hay, M. E. 1997. The ecology and evolution of seaweed-herbivore interactions on coral reefs. Coral Reefs. 16: S67-S76.

Hay, M. E. and J. N. Norris. 1984. Seasonal reproduction and abundance of six sympatric species of Gracilaria Grev. (Gracilariaceae; Rodhophyta) on a Caribbean subtidal sand plain. Hydrobiologia. 116/117: 63-94. 
Hay, M. E., W. Fenical. and K. Gustafson. 1987. Chemical Defense Against Diverse Coral Reef Herbivores. Ecology, 68 (6): 1581- 1591.

Hixon, M. A. and W. N. Brostoff. 1996. Succession and herbivory: effects of differential fish grazing on Hawaiian coral-reef algae. Ecological Monograph. 66(1): 67-90.

Hoegh-Guldberg, O., P. J. Mumby, A. J. Hooten, R. S. Steneck, P. Greenfield, E. Gomez, C. D. Harvell, P. F. Sale, A. J. Edwards, K. Caldeira, N. Knowlton, C. M. Eakin, R. IglesiasPrieto, N. Muthiga, R. H. Bradbury, A. Dubi, and M. E. Hatziolos. 2007. Coral reefs under rapid climate change and ocean acidification. Science. 318:1737-1742.

Hoey, A. S. and D. R. Bellwood. 2011. Suppresion of herbivory by macroalgal density: a critical feedback on coral reef? Ecology letters. 14: 267-273.

Hughes, T. P. 1994. Catastrophes, phase shifts, and large-scale degradation of a Caribbean coral reef. Science 265: 1547-1551.

Hughes, T. P; A. M. Szmant; R. Steneck; R. Carpenter and S. Miller. 1999. Algal blooms on coral reefs: What are the causes? Limnol. Oceanogr. 44(6): 1583-1586.

Jones, G. P., L. Santana, L. J. McCook and M. I. McCormick. 2006. Resource use and impact of three herbivorous damselfishes on coral reef communities. Mar. Ecol. Prog. Ser. 328: 215-224.

Kayal, M., J. Vercelloni, T. L. De Loma, P. Bosserelle, Y. Chancerelle, S. Geoffroy, C. Stievenart, F. Michonneau, L. Penin, S. Palnes and M. Adjeroud. 2012. Predator Crownof-Thorns Starfish (Acanthaster planci) Outbreak, Mass Mortality of Corals, and Cascading Effects on Reef Fish and Benthic Communities. PLoS ONE 7(10): e47363. doi:10.1371/journal.pone.0047363.

Kendrick, G. A. and D. I. Walker. 1991. Dispersal distances of Sargassum spinuligerum (Sargassaceae, Phaeophyta) measured directly by vital staining and venturisuction sampling. Mar. Ecol. Prog. Ser. 79: 133-138.

Kinlan, B. P. and S. D. Gaines. 2003. Propagules discpersal in marine and terrestrial environments: A community perspective. Ecology. 84 (8): 2007-2020.

Kinlan, B. P., S. D. Gaines and S. E. Lester. 2005. Propagule dispersal distance and the scales of marine community process. Diversity and distributions. 11 (2): 139-148.

Lapointe, B. E., M. M. Littler and D. S. Littler. 1993. Modification of benthic community structure by natural eutrophication: the Belize Barrier Reef. Proceeding of the seventh International Coral Reefs Symposium, Guam. 1: 323-334. 
Lapointe, B. E., M. M. Littler and D. S. Littler. 1997. Macroalgal overgrowth of fringing coral reefs at discovery bay, Jamaica: Bottom-up versus Top-down control. Proc $8^{\text {th }}$ Int. Coral Reef Sym 1:927-932.

Lapointe, B. E., P. J. Barile and W. R. Matzie. 2004. Anthropogenic nutrient enrichment of seagrass and coral reef communities in the Lower Florida Keys: discrimination of local versus regional nitrogen. Journal of experimental marine biology and ecology. 308:23-58.

Lapointe, B. E., P. J. Barile, M. M. Littler and D. S. Littler. 2005. Macroalgal blooms on southeast Florida coral reefs II. Cross-shelf discrimination of nitrogen sources indicates widespread assimilation of sewage nitrogen. Harmful Algae. 4: 1106-1122.

Lapointe, B. E; M. M. Littler and D. S. Littler. 1999. Simultaneous top-down and bottom-up forces control macroalgal blooms on coral reefs. (Reply to the comment by Hughes et al.). Limnol Oceanogr. 44(6): 1586-1592.

Lessios, H. A., D. R. Robertson and J. D. Cubit. 1984. Spread of Diadema mass mortality trough the Caribbean. Science. 226: 335-338.

Lewis, S. M. 1986. The role of herbivorous fishes in the organization of the Caribbean reef community. Ecol. Monogr. 56 (3): 183-200.

Littler, M. M. and D. S. Littler. 1984. Models of tropical reef biogenesis: the contribution of algae. Progress in Phycological research. 3: 323-364.

Littler, M. M., D. S. Littler and B. L. Brooks. 2006. Harmful algae on tropical coral reefs: Bottom-up eutrophication and top-down herbivory. Harmful Algae. 5: 565-585.

Lotze, H. K., B. Worm and U. Sommer. 2000. Propagule banks, herbivory and nutrient supply control population adevelopment and dominance patterns in macroalgal blooms. Oikos. 89: 46-58.

Lüning, K. 1990. Seaweeds. Their environment, biogeography and ecophysiology. Yarish, C. and H. Kirkam (eds). A wiley-Interscience publication. U.S: 527 pp.

Maggs, C. A, and M. E. Callow. 2002. Algal spores. In: Encyclopedia of life sciences. Nature Publishing Group, London: 1-6.

McClanahan, T. R. 1997. Primary succession of coral reef algae: differing patterns on fished versus unfished reefs. Journal of experimental marine biology and ecology. 218: 77-102.

McClanahan, T. R., B. A. Cokos, and E. Sala. 2002. Algal growth and species composition under experimental control of herbivory, phosphorus and coral abundance in Glovers Reef, Belize. Mar. Pollut. Bull, 44 (6): 441- 451. 
McClanahan, T. R., E. Sala, P. J. Mummby and S. Jones. 2004. Phosphorus and nitrogen enrichment do not enhance brown frondose "macroalgae". Marine Pollution Bulletin. 48: 196-199.

McClanahan, T. R., M. Carreiro-Silva and M. DiLorenzo. 2007. Effect of nitrogen, phosphorous, and their interaction on coral reef algal succession in Glover's Reef, Belize. Marine Pollution Bulletin. 54: 1947-1957.

Milicich, M. J. 1994. Dynamic coupling of reef fish replenishment and oceanographic processes. Mar. Ecol. Prog. Ser. 110: 135-144.

Milicich, M. J., M. G. Meekan and P. J. Doherty. 1992. Larval supply: a good predictor of recruitment of three species of reef fish (Pomacentridae). Mar. Ecol. Prog. Ser. 86: 153166.

Mumby, P. J. 2009. Phase shift and the stability of macroalgal communities on Caribbean coral reefs. Coral Reefs. 28: 761-773 p.

Mumby, P. J. and R. S. Steneck. 2008. Coral reef management and conservation in light of rapidly evolving ecological paradigms. Trends in Ecology and Evolution. 23 (10): 555563.

Mumby, P. J., C. P. Dahlgren, A. R. Harborne, C. V. Kappel, F. Micheli, D. R. Brumbaugh, K. E. Holmes, J. M. Mendes, K. Broad, J. N. Sanchirico, K. Buch, S. Box, R. W. Stoffle and A. B. Gill. 2006. Fishing, trophic cascades, and the process of grazing on coral reefs. Science. 311: 98-101.

Norton, T. A. 1992. Dispersal by macroalgae. British Phycological Journal. 27(3): 293-301.

Okuda, T. and M. Neushul. 1981. Sedimentation studies of red algal spores. Hournal of phycology. 17 (2): 113-118.

Pandolfi, J.M., R.H. Bradbury, E. Sala, , T.P Hughes, K.A. Bjorndal, R.G. Cooke, D. McArdle, L. McClenachan, M.J.H. Newman, G. Paredes, R. R. Warner and J. B.C. Jacksonl. 2003. Global trajectories of the long-term decline of coral reef ecosystems. Science. 301: 955958.

Reed, D. C., D. R. Laur and A. W. Ebeling. 1988. Variation in algal dispersal and recruitment: the importance of episodic events. Ecology Monographs. 58 (4): 321-335.

Reed, D. C., S. C. Schoroeter and P. T. Raimondi. 2004. Spore supply and habitat availability as sources of recruitment limitation in the giant kelp Macrocystis pyrifera (Phaeophyceae). J. Phycol. 40: 275-284. 
Robersson, D. R. and K. W. Kaufmann. 1998. Assesing early recruitment dynamics and its demographic consequences among tropical reef fishes: Accommodating variation in recruitment seasonality and longevity. Australian journal of ecology. 23: 226-233.

Rogers, C. S. and J. Miller. 2006. Permanent 'phase shifts' or reversible declines in coral cover? Lack of recovery of two coral reefs in St. John, US Virgin Islands. Mar. Ecol. Prog. Ser. 306: $103-114$.

Sale, P. F. 2004. Connectivity, recruitment variation, and the structure of reef fish communities. Integr. Comp. Biol. 44: 390-399.

Sammarco, P.W. 1982. Echinoid grazing as a structuring force in coral communities: whole reef manipulations. J. Exp. Mar. Biol. Ecol. 61: 31-35.

Sammarco, P. W. 1983. Effects of fish grazing and damselfish territoriality on coral reef algae. I. Algal community structure. Mar. Ecol. Prog. Ser. 13: 1-14.

Santos, R. and P. Duarte. 1996. Fecundity, spore recruitment and size in Gelidium sesquipedale (Gelidiales, Rhodophyta). Hydrobiologia. 326/327: 223-228.

Schupp, P. J. and V. J. Paul. 1994. Calcium carbonate and secondary metabolites in tropical seaweeds: variable effects on herbivorous fishes. Ecology. 75 (4):1172-1185.

Smith, J., C. Hunter and C. Smith. 2010. The effects of top-down versus bottom-up control on benthic coral reef community structure. Oecologia 163:497-507.

Smith, J. E., J. W. Runcie and C. M. Smith. 2005. Characterization of a large-scale ephemeral bloom of the green alga Cladophora sericea on coral reefs of West Maui, Hawai. Mar. Ecol. Prog. Ser. 302: 77-91.

Smith, S. V. 1984. Phosphorus versus nitrogen limitation in the marine environment. Limnol. Oceanogr. 29(6):1149-1160.

Solandt, J-L. and A. C. Campbell. 2001. Macroalgal feeding characteristics of the sea urchin Diadema antillarum philippi at discovery bay, Jamaica. Caribbean journal of science. 37 (3-4): 227-238.

Sotka, E. E. and M. E. Hay. 2009. Effects of herbivores, nutrient enrichment, and their interactions on macroalgal proliferation and coral growth. Coral Reefs. 28:555-568.

Steiner, S. C. C. and S. M. Williams. 2006. The density asn size distribution of Diadema antillarum in Dominica (Lesser Antilles): 2001-2004. Marine Biology.149: 1071-1078.

Steneck, R. S. 1983. Quantifying herbivory on coral reefs: Just scratching the surface and still biting off more than we can chew. In "The ecology of deep and shallow coral reefs". L. 
Reaka (ed.), Simposia Series for Undersea Reserarch, NOAA'S Undersea Research Program. 1(1): 103-111.

Steneck, R. S. and M. N. Dethier. 1994. A functional group approach to the structure of algaldominated communities. Oikos. 69: 476-498.

Stiger, V. and C. E. Payri. 1999. Spatial and temporal patterns of settlement of the brown macroalgae Turbinaria turbinata and Sargassum mangarevense in a coral reef on Tahiti. Mar. Ecol. Prog. Ser. 191:91-100.

Stoner, A. W., R. A. Glazer and P. J. Barile. 1996. Larval supply to Queen Conch nurseries: Relaitonships with process and population size in Florida and the Bahamas. Journal of Shellfish Research. 15 (2): 407-420.

Targett, N. M., T. E. Targett, N. H. Vrolijk and J. C. Ogden. 1986. Effects of macrophyte secondary metabolites on feeding preferences of the herbivorous parrotfish Sparisoma radians, Marine biology. 92:141-148.

Tilghman, G. C., R. Klinger-Bowen and R. Francis-Floyd. 2001. Feeding selectivity indices in surgeonfish (Acanthuridae) of the Florida Keys. Aquarium Sciences and Conservation. 3: 215-223.

Walsh, S. M. 2011. Ecosystem-scale effects of nutrients and fishing on coral reefs. Journal of marine biology. doi: 10.1155/2011/187248: 13.

Walters, L. J., C. M. Smith, J. A. Coyer, C. L. Hunter, K. S. Beach and P. S. Vroom. 2002. Asexual propagation in the coral reef macroalga Halimeda (Chlorophyta, Bryopsidales): production, dispersal and attachment of small fragments. Journal of experimental marine biology and ecology. 278: 47-65.

Wilson, D. T. and M. G. Meekan. 2001. Environmental influences on patterns of larval replenishment in coral reef fishes. Mar. Ecol. Prog. Ser. 222: 197-208.

Worm, B., H. K. Lotze and U. Sommer. 2001. Algal propagule banks modify competition, consumer and resource control on Baltic rocky shores. Oecologia. 128: 281-293.

Zhang, Q. S., Y. Z. Tang, S. K. Liu, S. B. Zhang, Z. C. Lu. S. H. Cu and Y. Q. Yu. 2012. Zygote-derive seedling production of Sargassum thurbergii: focus on two frequently experienced constraints in tank culture of seaweed. J. Appl. Phycol. 24:707-714. 


\title{
CHAPTER 2 - RECRUITMENT AND SUCCESSION OF CORAL REEF MACROALGAL COMMUNITIES UNDER DIFFERENT ECOLOGICAL DRIVERS
}

\begin{abstract}
Structure of coral reef macroalgal communities is shaped by herbivory pressure and nutrient availability. However, the magnitude of impact of both ecological drivers throughout macroalgal succession remains unclear. Current study evaluated the effects of herbivory pressure, nutrient availability and potential propagule supply, on recruitment and succession of coral reef macroalgae. In September 2011, two limestone tiles were placed in a nutrient-herbivory factorial experiment (25 quadrats). One tile (recruitment tiles) was replaced every three months and abundance of algal species was evaluated in the lab. The remaining tile (succession tiles) was kept in the field throughout the nine-month study period. Percent cover of macroalgal formfunctional groups of succession tiles and field established communities within quadrats were assessed in January and June, 2012. Total abundance of macroalgae increased towards June in recruitment and succession tiles and field established communities. Proportional abundance of macroalgal form-functional groups on recruitment and succession tiles were similar to field established communities suggesting possible effects of adult macroalgae as potential propagule supply. Macroalgal abundance of early successional species increased with combined nutrient loading and herbivore removal on recruitment tiles whereas on succession tiles nutrient increased percent cover of articulated calcareous species only when herbivores were excluded. Additionally, nutrients did not affect the abundance of macroalgae in field established communities. In summary, nutrient loading level and herbivory pressure controlled macroalgal communities at early-stages while effects of nutrient loading tended to decrease towards latesuccessional stages. Moreover, adult assemblages of coral reef macroalgae could affect recruitment and post-settlement succession.
\end{abstract}




\subsection{Introduction}

In coral reefs, special attention has been paid to herbivory pressure and nutrient availability as primary ecological drivers of macroalgal communities (Sammarco, 1983; Lewis, 1986; Hixon and Bostroff, 1996; Lapointe et al., 2004; Burkepile and Hay, 2006). However, the relative magnitude of the effect of each ecological driver has on structuring macroalgal assemblages is still under debate, since increases of macroalgal abundance in some coral reefs have been attributed to either eutrophication or reduction of herbivores (Littler et al., 1993; Hughes 1994; Lapointe et al., 1997; Thacker et al., 2001; Littler et al., 2006; Rasher et al., 2012). However, grazing rates of herbivorous fishes vary with season and depends on nutritional value and chemical defenses of macroalgal species (Hay et al., 1987; Bolser and Hay, 1996; Boyer et al., 2004; Burkepile and Hay, 2009, 2010). Furthermore, it is known that coral reef macroalgal species respond differently to nutrient loading since some species (e.g., opportunistic fast-growing) could quickly increase growth rates in nutrient enriched environments (Lapointe et al., 1993; Lapointe et al., 1997; McClanahan et al., 2004; Smith et al., 2005). However, when referring to the abundance of frondose algal species, the controlling effect of nutrient loading remains uncertain (Hugher, 1994; Hughes et al., 1999; McCLanahan et al., 2004). Additionally, abundance of coral reef macroalgae species changes seasonally responding to temporal variations of environmental conditions such as salinity, water temperature and light availability (Stiger and Payri, 1999; Ferrarri et al., 2012). Hence, the effect of herbivory pressure and nutrient availability on controlling coral reef macroalgae might vary seasonally, locally and is content dependent.

Plant communities are subjected to progressive temporal changes of both species richness and abundance, defined as community succession (Grime, 1979). Furthermore, terrestrial 
ecologists have classified primary succession as colonization of substrate that has never been previously occupied and secondary succession as recolonization after disturbances open free space (Moore et al., 1998). In marine communities some macroalgae have been classified as early-successional species (e.g., filamentous turf algae such as Ectocarpus sp., and Ulva spp.) whereas others as late-successional species (e.g., Sargassum sp., Corallina sp., Amphiroa sp.) on the basis of their growth and reproduction rates, and morphological characteristics (Littler and Littler, 1980; Dawes, 1998). Biological traits of early-successional species include small size, year-around reproductive cycle, and high growth rates that allow them to rapidly colonize available substrate (Steneck and Dethier, 1994; McClanahan, 1997). Conversely, late successional forms include taller species with higher thallus complexity characterized by slow growth and reproduction rates and usually more resistant to grazing through physical and chemical defenses (Steneck and Dethier, 1994).

Recruitment of macroalgae relies upon several factors such as number of propagules released by parents (propagule supply), propagule dispersal distance, as well as abiotic factors such as space availability, currents, and water temperature (Callow et al., 1997; Lotze et al., 2000; Worm et al., 2001). However, while only few studies have focused on coral reefs, the effects of macroalgal propagule supply on structuring macroalgal marine communities has been mostly studied at temperate ecosystems such as kelp forests and rocky shore, and single, invasive and blooming species (Kendrick and Walker, 1991; Stiger and Paire, 1999; Lotze et al., 2000; Reed et al., 2004; Zhang et al., 2009). Yet, coral reefs have highly diverse macroalgal communities with over 700 species that can reproduce sexually and asexually releasing millions of propagules that could be recruited within approximately one meter from the parent plant (Kendrick and Walker, 1991; Stiger and Payri, 1999; Zhang et al., 2012). Further, macroalgal 
reproduction periods are triggered by physical factors such as water temperature, tide cycles, photoperiod and natural disturbances (Hay and Norris, 1984; Luning, 1990; Clifton, 2008). Consequently, multiple species of macroalgae provide propagules that settle on available coral reef space at any given time. Therefore, macroalgal propagule supply may be an important, but underappreciated, driver of macroalgal recruitment and post- settlement succession on coral reefs.

Furthermore, post-settlement success, growth rate, and competition among germlings are controlled primarily by herbivory, nutrient availability, and light availability, among other biotic and abiotic factors (Foster, 1975; Lapointe et al., 1981; Greene et al., 1983; Vance, 1988; Hill et al., 2004; Karez et al., 2004; Collado-Vides et al., 2011; Guimaraens et al., 2011). For instance, some authors have shown herbivory as the primary driver since abundance of coral reef macroalgal assemblages has dramatically increased when herbivores are excluded (Lewis, 1986; Hixon and Brostoff, 1996; Burkepile and Hay, 2009; Sotka and Hay, 2009; Ferrari et al., 2012; Poore et al., 2012). Conversely, Lapointe et al. (2010) reported increased macroalgal abundance as solely a consequence of eutrophication on coastal marine ecosystems. Further, Smith et al. (2010) indicated that both herbivores and nutrient availability control algal community structure on coral reefs but on different time scales. According to Smith et al. (2010), effects of herbivore reduction will be noticed in less than a month while the effects of nutrient enrichment will be visible after three to four months.

Most of the research evaluating the relative magnitude of both nutrient availability and herbivory pressure on controlling abundance of macroalgae have focused on adult macroalgal assemblages (Burkepile and Hay, 2006; Sotka and Hay, 2009; Ferrarri et al., 2012; Rasher et al., 2012). However, it is known that species composition and abundance of coral reef macroalgal 
communities could change through time following dissimilar successional patterns, as a consequence of type and intensity of grazing (Hixon and Bostroff, 1996; McClanahan, 1997; Burkepile and Hay, 2010). In particular, herbivorous fishes are described as major drivers of macroalgal succession compared with others such as micro-herbivores (small gastropods, polychaetes, etc.) and long-spined sea-urchin Diadema antillarum (Hay, 1984; Carpenter, 1986). Indeed, herbivore exclusion experiments report that after 11 months, only uncaged areas (grazed by herbivorous fish) were still covered by early-successional species and bare substrate (Sammarco, 1983). Furthermore, Hixon and Brostroff (1996) showed a successional deceleration, a slower succession rate, with damselfish activity as they selectively removed latesuccessional species. Conversely, high grazing intensity by parrotfish and surgeonfish in uncaged areas shifted early successional species towards crustose and prostrate species that were rare or absent in ungrazed areas, defined as a deflected successional pattern (Hixon and Bostroff, 1996).

In addition to herbivory, nutrient availability is also considered one of the major drivers of tropical marine primary producers (Duarte, 1992; Fourqurean et al., 2002; Szmant, 2002; Lapointe et al., 2004; Collado-Vides et al., 2011). Indeed, growth rate and abundance of marine macroalgae increase when systems are enriched with nitrogen and phosphorus (Pedersen and Borum, 1997; Larned, 1998; Kuffner and Paul, 2001; Bracken and Nielsen, 2004). However, all macroalgal species do not respond similarly to nutrient enrichment, which could be related to multiple factors such as differences in morphology, initial tissue nutrient status, and species physiology (Learned, 1998; Reef et al., 2012; Fong et al., 2001; Kuffner and Paul, 2001; Fong et al., 2003). In particular, fast-growing species typical of early successional stages (e.g., Chaetomorpha sp., Ceramium sp., Ulva sp., Cladophora sp. and cyanobacteria) are well known 
for their rapid increase in abundance following increases in nutrient loading (Lapointe et al., 1993; Lapointe et al., 2005; Smith et al., 2005). In contrast, the effect of nutrient enrichment on abundance of mature late successional species is still unclear (Hughes, 1994; McClanahan et al., 2004). Indeed, recent studies suggest that nutrient availability would play a secondary role on controlling adult macroalgal growth only if herbivory pressure level is low or absent (Burkepile and Hay, 2009; Sotka and Hay, 2009; Walsh, 2011).

The general objective of the study was to evaluate seasonal recruitment and postsettlement succession of coral reef macroalgal communities in relation with potential propagule supply under different levels of herbivory pressure and nutrient availability. The specific objectives were: 1) to assess the effect of herbivory pressure and nutrient availability on the abundance of adult macroalgae as potential propagule sources, 2) to evaluate the effect of nutrient availability and herbivory pressure on seasonal recruitment of macroalgal species, and 3) assess the effects of herbivory pressure and nutrient availability on succession of coral reef macroalgal communities. We hypothesized that: 1) reductions in herbivory and increases in nutrient availability will increase abundance of adult macroalgae and indirectly facilitate macroalgal recruitment via increased propagule supply, 2) increases in nutrient availability and reduction of herbivore pressure will increase abundance of macroalgal recruits, enhancing successional rates and 3) reduction of herbivore pressure rather than nutrient availability will accelerate successional rate of macroalgal communities.

\subsection{Materials and methods}

\section{Study site and experimental design}

The study was conducted at a spur and groove reef system, located in the upper Florida Keys $\left(25^{\circ} 00^{\prime} 05^{\prime} \mathrm{N}, 80^{\circ} 24^{\prime} 55^{\prime} \mathrm{W}\right)$ nearby Pickles Reef. The reef is a mid-depth area (5-6 m) off 
of Key Largo, where parrotfish and surgeonfish are the dominant herbivorous fish and the longspined urchin Diadema antillarum is present at low densities $\left(<1\right.$ individual per $50 \mathrm{~m}^{2}$, personal observations). Eight experimental plots $(3 \times 3 \mathrm{~m})$ separated from each other by at least $5 \mathrm{~m}$ (Figure 1) were established in June 2009 to examine the interactive effects of herbivory and nutrient availability on reef benthic dynamics. Each plot was delineated with metal nails driven into the reef at the corners and centers of each $1 \mathrm{~m}^{2}$ subplot (quadrat). Each plot contains two quadrats $\left(1 \times 1 \mathrm{~m}^{2}\right)$ for herbivore exclosure covered with plastic-coated wire mesh $(2.5 \mathrm{~cm}$ diameter holes). Two other three-sided plots $\left(1 \mathrm{x} 1 \mathrm{~m}^{2}\right)$ were used as herbivore exclosure controls (Figure 2). Four of the eight $9 \mathrm{~m}^{2}$ experimental plots were enriched with total $4375 \mathrm{~g}$ of Osmocote (19-6-12, N-PK) slow-release garden fertilizer since June 2009. The Osmocote was placed in a $15 \mathrm{~cm}$ diameter PVC tube with $10(1.5 \mathrm{~cm})$ holes drilled into it. These tubes were open on each end but wrapped in fine plastic mesh to keep the fertilizer inside and attached to a metal nail within the plot for a total of 25 enrichment tubes (175 g of Osmocote) per enrichment plot. Enrichment tubes were replaced every 4-6 weeks to ensure consistent nutrient addition. The field sampling period was meant for a full year but as a consequence of Hurricane Isaac in August 2012, the study took place from September 2011 to June 2012 and laboratory work from January 2012 to September 2012. As a consequence of tropical storm damages, the sample size was different among treatments: $\mathrm{NE}=5$ (Nutrient enrichment-Exclusion), $\mathrm{CE}=4$ (Control-Exclusion), $\mathrm{CO}=8$ (ControlOpen) and $\mathrm{NO}=8$ (Nutrient enrichment-Open). 


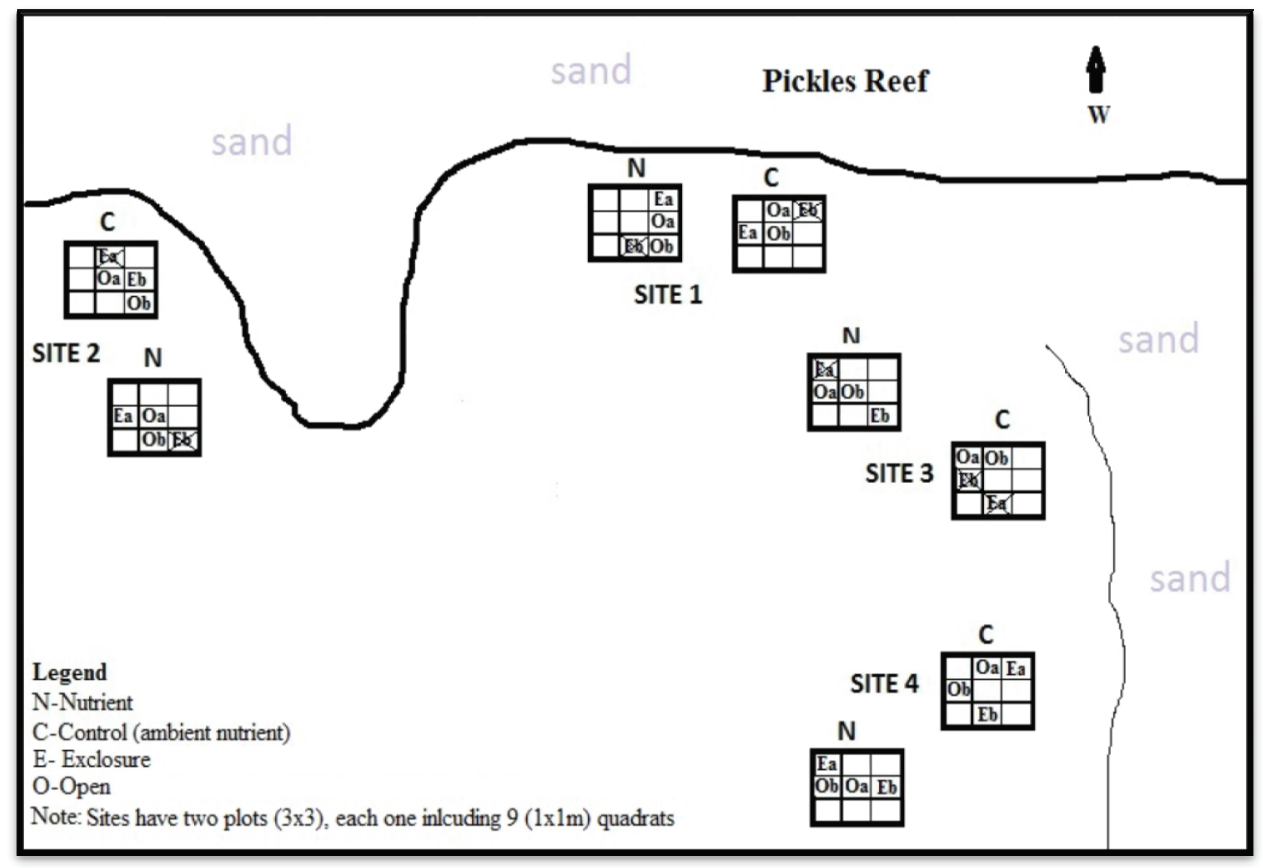

Figure 2. Study site and experimental design

\section{Fish community structure and nutrient levels of the study site}

Fish community structure was evaluated four times during the study period (September, 2011; January, 2012; April, 2012 and July 2012) via 30 x $2 \mathrm{~m}$ belt transects $(\mathrm{n}=12)$ placed haphazardly across the study site following AGRRA methodology (Protocols Version 5.4; Lang et al., 2010). All fishes were identified and their size estimated to the nearest $\mathrm{cm}$. Size estimates were converted to biomass for each fish using published length:weight relationships (Bohnsack and Harper, 1988). Density and biomass of total and herbivorous fish were estimated at each time.

To evaluate the effectiveness of nutrient enrichment treatments versus ambient nutrient controls of the experiment, twenty samples of water (nutrient enrichment treatment $=10$ and control treatment $=10$ ) were collected by divers from approximately $3 \mathrm{~cm}$ above the benthos in July 2009 to be analyzed for dissolve inorganic nitrogen (DIN) and soluble reactive phosphorous (SRP). A few minutes after collection, samples were filtered into acid-washed bottles and placed 
on ice for posterior laboratory analyzes. Dissolved inorganic nitrogen (DIN $=$ ammonium and nitrite + nitrate) and soluble reactive phosphorus (SRP) concentrations were determined via autoanalyzer. Additionally, twenty samples of Dictyota sp. were collected in July and August 2009, ( $\mathrm{n}=10$ control, $\mathrm{n}=10$ enriched treatments) to analyze tissue carbon:nitrogen $(\mathrm{C}: \mathrm{N})$ levels. Collected algal material was kept in separate bags and transported on ice to the Florida International University Seagrass Lab. Once in the lab, the samples were clean, dried for 48 hours at $60{ }^{\circ} \mathrm{C}$ and ground to a fine powder. Carbon and nitrogen content were determined using a CHN analyzer (Fisons NA1500; Fisons Instruments, Milan, Italy; Fourqurean et al., 1992).

\section{Field established communities}

Abundance (\% cover) of field established macroalgal communities within each square meter quadrat $(\mathrm{n}=25)$, hereafter field established communities, was visually assessed at the formfunctional groups (FFG, Steneck and Dethier, 1994) in January and June 2012. Macroalgal species were identified following criteria of Littler and Littler (2000) and Dawes and Mathieson (2008) identification keys. A list of species was created from field and laboratory (recruitment tiles) observations to determine the pool of potential existing species available for propagule settlement (Appendix 1 shows the list of algal species identified throughout the study and corresponding form-functional group).

\section{Recruitment of coral reef macroalgal communities}

To study macroalgal recruitment and succession, two tiles $(10 \times 10 \mathrm{~cm})$ made of Pleistocene coral skeleton were placed inside each quadrat in September 2011. One of the tiles (recruitment tile) was replaced every three month (set I: September-December 2011, set II: December 2011-March 2012 and set III: March- June, 2012). After three months in the field, recruitment tiles were taken to the FIU Marine Macroalgae Research Laboratory and placed in 
individual aquariums previously prepared to replicate the field conditions as closely as possible (salinity: $35-36 p p t$, temperature: $25-28^{\circ} \mathrm{C}$, constant water circulation and air pump). Light values were elevated to $369 \pm 58 \mu \mathrm{mol} / \mathrm{s} / \mathrm{m}^{2}$ at the surface and $163 \pm 19 \mu \mathrm{mol} / \mathrm{s} / \mathrm{m}^{2}$ at the bottom. The light cycle at the laboratory was set up with four fluorescent low output bulbs (Lithonia Lighting All Season Shoplight) from 6:00am to 8:00pm $\left(\sim 50 \mu \mathrm{mol} / \mathrm{s} / \mathrm{m}^{2}\right.$ underwater $)$ and two Very High Output bulbs (VHO) from 8:00am to 6:00pm ( $162 \mu \mathrm{mol} / \mathrm{s} / \mathrm{m}^{2}$ underwater). For recruitment tiles, two evaluation rounds of percent cover at the lowest taxonomic possible level occurred at the laboratory, one evaluation immediately after retrieving the tiles from the field and the second evaluation after three months in laboratory conditions. Tiles were kept in aquariums to promote growth of algae recruits that could not be identified in the first evaluation round as a consequence of too small size or lacking of identifiable species features.

\section{Succession of coral reef macroalgal communities}

For macroalgae successional patterns, the second tile (succession tile) was kept in the field during the entire study period (September 2011 to June 2012). Percent cover of succession tiles at FFG level, following a Steneck and Dethier (1994) classification, was recorded "in situ" in January and June, 2012.

\section{Statistical analyses}

Data were assessed for normality and homogeneity of variances using Levene's test before running statistical analysis. When data did not conform to assumptions of normality and homogeneity, the data were transformed as appropriate. Biomass and density of total and herbivorous fish were compared between seasons using one-factor ANOVAs. Dissolve inorganic nitrogen (DIN) and soluble reactive phosphorus (SRP) in water and Dictyota sp. tissue nutrient content, carbon $(\mathrm{C})$, nitrogen $(\mathrm{N})$, and $\mathrm{C}: \mathrm{N}$ ratio were compared between treatments using one- 
factor ANOVA. Macroalgae abundances among treatments and seasons were statistically evaluated through three-factor ANOVA (nutrient, herbivores and season). In the case of leathery and articulated calcareous macroalgae FFG, statistical analyses were carried out using KruskalWallis since data could not be normalized using transformation.

To evaluate possible effects of both nutrient and herbivory levels on macroalgal species diversity, differences in diversity indexes (richness, Margalef diversity and Shannon heterogeneity index) calculated from recruitment tiles among sets were statistically tested with one-factor ANOVAs and among treatments with Kruskal Wallis. A Similarity Percentages (SIMPER) analysis was used to estimate the most abundant species among treatments. Analyses of most common species abundances were carried out with parametric or non-parametric tests as shown in table 3. Multi-dimensional Scaling (MDS) and Analysis of similarity (ANOSIM) were performed to calculate the effects of treatments and seasonality on macroalgae composition of recruitment tiles. To estimate the possible role of field established communities as potential propagule supply, Pearson correlation analyses using overall and FFG abundances of macroalgae were run: 1) set II of recruitment tiles (Dec-Mar) and January surveys of field established communities, 2) Set III of recruitment tiles (Mar-Jun) and June surveys of field established communities, 3) January surveys of succession tiles and field established communities, 4) June surveys of succession tiles and field established communities. To evaluate macroalgal abundance of succession tiles among treatments and seasons three-factor ANOVA (herbivores, nutrients and seasons) were used. In the case of filamentous, corticated foliose, leathery, articulated calcareous and crustose, Kruskal Wallis was used to evaluate treatment and season effects. Multidimensional Scaling and ANOSIM analyses were performed with abundance of all FFG to calculate the effects of treatments on community succession. Descriptive, parametric and non- 
parametric analyses such as ANOVAs, correlations and Kruskall Wallis were performance using SPSS version 19.0 software package, whereas MDS and SIMPER analyses were completed with PRIMER 6.1.5 software package.

\subsection{Results}

\section{Fish community structure and nutrient levels of the study site}

Means of overall fish biomass and density at the study site were $6495.6 \pm 508.1 \mathrm{~g} / 100 \mathrm{~m}^{2}$, and 39.9 \pm 3.2 Ind. $/ 100 \mathrm{~m}^{2}$ respectively. Grazers (Family Scaridae and Acanthuridae) comprised $78 \%$ of overall fish biomass with an average of $5086.1 \pm 569.5 \mathrm{~g} / 100 \mathrm{~m}^{2}$, and $74 \%$ of overall fish density $29.9 \pm 2.1$ Ind./100m ${ }^{2}$. Total biomass of parrotfish and surgeonfish were $2771.7 \pm 526.6$ $\mathrm{g} / 100 \mathrm{~m}^{2}$ and $2315.5 \pm 370.6 \mathrm{~g} / 100 \mathrm{~m}^{2}$ respectively. There were no differences among seasons of total fish (Figure 3, one-factor ANOVA, $\mathrm{F}=0.23, p=0.885$ ) or herbivore biomass (one-factor ANOVA, $\mathrm{F}=0.30, p=0.82$ ). Similarly, there was no evidence of seasonality on total fish density $(\mathrm{F}=0.45, p=0.72)$ or herbivorous fish density (Figure 3, one-factor ANOVA, $\mathrm{F}=0.75, p=0.53$ ).
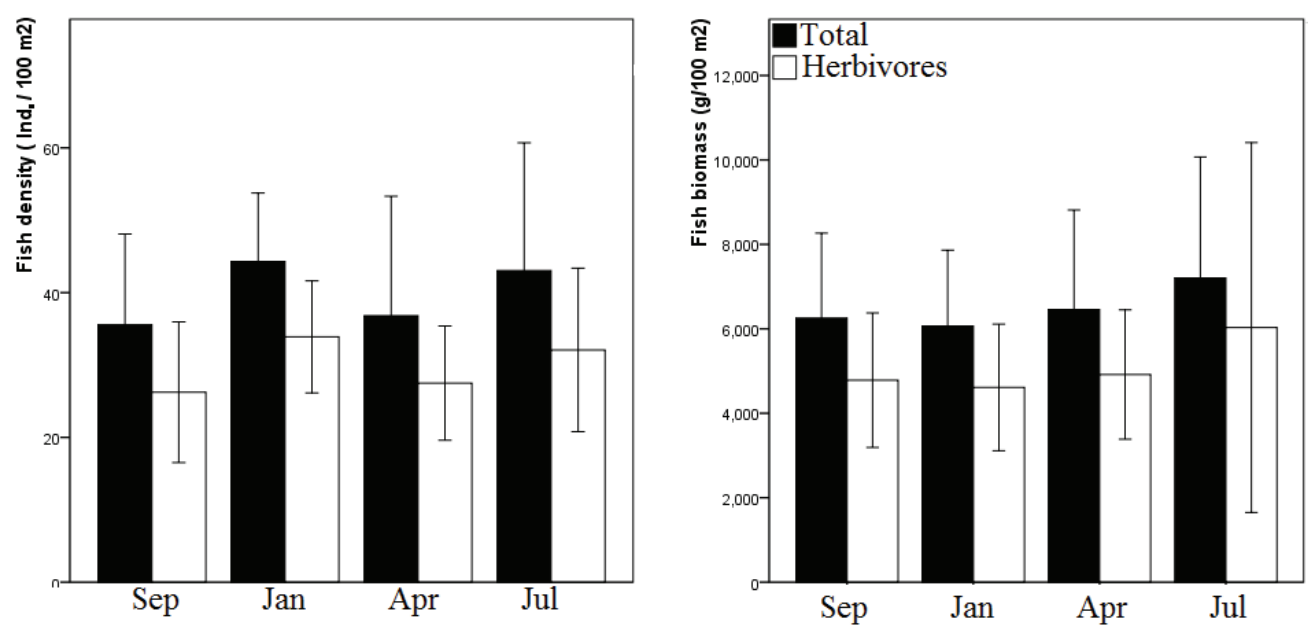

Figure 3. Total and herbivorous fish biomass and density at experimental site during the four sampling seasons. Bars represent standard errors 
Dissolve inorganic nitrogen (DIN) and soluble reactive phosphorus (SRP) of water surrounding experimental plots, were threefold and sixfold higher in enriched plots than ambient plots respectively (Table 1). No statistical differences were found on Carbon (C) and nitrogen (N) tissue content of Dictyota sp., but C:N ratio in control treatments resulted 1.14 higher $(p=0.01)$ than enriched nutrient treatments (Table 1$)$.

Table 1. Water nutrient contents (DIN and SRP) and percentage of nutrient tissues of Dictyota sp (carbon $(\mathrm{C})$, nitrogen $(\mathrm{N})$ and carbon:nitrogen $(\mathrm{C}: \mathrm{N})$ in ambient and enriched nutrient treatments

\begin{tabular}{|c|c|c|c|c|c|c|}
\hline \multirow{2}{*}{ Nutrient } & \multicolumn{2}{|c|}{ Ambient nutrient } & \multicolumn{2}{|c|}{ Nutrient enrichment } & \multicolumn{2}{|c|}{ Statistical } \\
\cline { 2 - 7 } & Mean & St. error & Mean & St. error & F & $p$ \\
\hline Disolved inorganic nitrogen (DIN) & 1.15 & 0.05 & 3.91 & 1.34 & N/A & $0.002^{* *}$ \\
\hline Soluble reactive phosphorus (SRP) & 0.04 & 0.01 & 0.27 & 0.07 & 10.7 & $0.02^{* *}$ \\
\hline Carbon (C) & 22.44 & 0.79 & 22.47 & 1.27 & 0.179 & 0.676 \\
\hline Nitrogen (N) & 1.11 & 0.05 & 1.27 & 0.09 & 1.688 & 0.206 \\
\hline C:N & 20.53 & 0.57 & 17.98 & 0.55 & 9.821 & $0.004^{* *}$ \\
\hline
\end{tabular}

\section{Field established communities}

Including field and laboratory observations, 101 algal species were identified, with 60 species belonging to the Rhodophyta, 11 to Ochrophyta, 26 Chlorophyta, Phyla, and 4 Cyanobacteria (Appendix 1). Overall algal cover of field established communities was lower in January, $33.4 \pm 5.5 \%$ and over twofold higher in June with $83.3 \pm 6.2 \%$ (three-factor ANOVA, $\mathrm{F}=151.30, p=0.001)$. Furthermore, abundance of overall macroalgae of field established communities was twofold higher within cages compared to open areas, with $89.6 \%$ and $40.1 \%$ respectively (Figure 4, three-factor ANOVA F=149.20, $p=0.001$ ) and a significant interaction between season and herbivores factors was found (three-factor ANOVA, $\mathrm{F}=41.2, p=0.001$ ). No effects of nutrient treatment or its interactions with season and herbivores factors over macroalgal cover in field established communities were found (Figure 4. three-factor ANOVA, nutrient $\mathrm{F}=3.8, p=0.059$; nutrient-season $\mathrm{F}=0.10, \mathrm{p}=0.730$; nutrient-herbivore $\mathrm{F}=1.30, p=0.262$ ). 

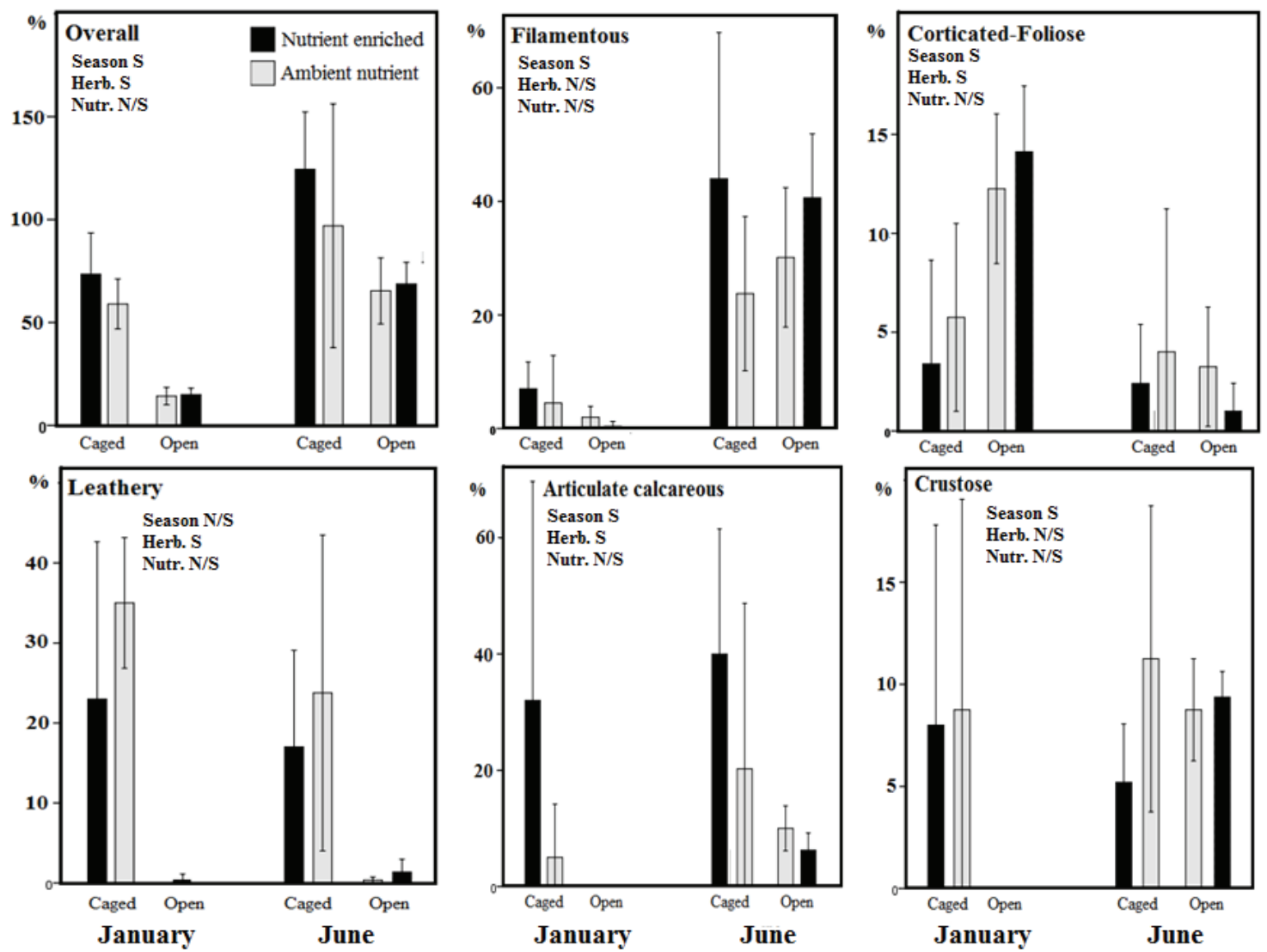

Figure 4. Percent cover of overall macroalgae and form-functional groups of field established communities in January and June. Bars represent standard errors. Statistical significant of analyzed variables, season, herbivores and nutrient, are indicated by S (significant) and N/S (no significant).

In field established communities percent cover of filamentous algae in June was $35.2 \pm 3.2$ $\%$, tenfold higher than January with $2.9 \pm 0.8$ (Krukal Wallis $p=0.001$ ). No effects of either nutrient enrichment or herbivorous exclusion were found (Figure 4, Kruskal Wallis, nutrient $p=0.43$; herbivores $p=0.34$ ). Corticated-foliose macroalgae (e.g., Dictyota spp.) showed a significant cover decrease in June compare with January (Figure 4, three-factor ANOVA, $\mathrm{F}=33.81, p=0.001)$. In January, field established communities had higher percent cover of corticated foliose algae in uncaged (Open) compared to caged treatments (three-factor ANOVA, $\mathrm{F}=12.42, p=0.001$ ) whereas nutrient did not indicate statistical significance at any season (Figure 4, three-factor ANOVA F=1.02, $p=0.318$ ). Abundances of leathery macroalgae (e.g., Sargassum spp.) was dramatically higher (over 40 times) within cages compared to open treatments (Figure 
4, $p=0.001$ ). Conversely, no seasonal changes or nutrient enrichment effect were observed (Kruskal Wallis $p=0.49$ and $p=0.75$ respectively). Calcareous articulated algae (e.g., Amphiroa spp. and Jania spp.) were over fivefold higher when herbivorous fish were excluded in both seasons ( $p=0.01$ respectively). Percent cover of articulated calcareous algae showed a two-fold increase from January towards June (Kruskal Wallis, $p=0.001$ ). No nutrient enrichment effects on abundance of articulated calcareous algae were detected (Kruskal Wallis, $p=0.557$ respectively). Abundance of crustose algae (e.g., Peyssonelia sp. and crustose coralline algae, CCA) was twofold higher in June, $8.6 \pm 0.8$ compared 3.0 1.4 in January (Kruskall Wallis, $p=0.001)$. No statistical effects of either nutrients or herbivores were found in crustose percentage cover (Kruskall Wallis, $p=0.760, p=0.114$ respectively).

There was a significant correlation of overall macroalgal abundances of field established communities with corresponding recruitment tiles in January (January-Set II $\mathrm{r}=0.59, p=0.002$ ); and June (June-Set III $\mathrm{r}=0.53, p=0.006$ ). Moreover, there was a significant relationship in total abundance between permanent tiles in January and June with field established communities $(\mathrm{r}=0.86, p=0.001 ; \mathrm{r}=0.43, p=0.031$, respectively). Furthermore, abundance of field established communities at form-functional group, articulated calcareous and leathery macroalgae, was correlated with the abundances found on recruitment and succession tiles in January and June (Table 2). 


\begin{tabular}{|c|c|c|c|c|c|}
\hline \multirow{2}{*}{ Season } & \multirow{2}{*}{ Form-Functional group } & \multicolumn{2}{|c|}{ Recruitment tiles } & \multicolumn{2}{c|}{ Succession tiles } \\
\cline { 3 - 6 } & & Coef. Corr (r) & $\boldsymbol{p}$ & Coef. Corr (r) & $\boldsymbol{p}$ \\
\hline \multirow{4}{*}{ January } & Filamentous & 0.89 & 0.11 & 0.35 & 0.65 \\
\cline { 2 - 6 } & Corticated-Foliose & 0.49 & 0.51 & 0.44 & 0.56 \\
\cline { 2 - 6 } & Leathery & $\mathbf{0 . 9 7}$ & $\mathbf{0 . 0 3}$ & 0.28 & 0.72 \\
\cline { 2 - 6 } & Articulated-Calcareous & $\mathbf{1 . 0 0}$ & $\mathbf{0 . 0 0}$ & $\mathbf{0 . 9 9}$ & $\mathbf{0 . 0 1}$ \\
\cline { 2 - 6 } June & Crustose & -0.94 & 0.04 & -0.77 & 0.23 \\
\hline & Filamentous & -0.33 & 0.67 & -0.51 & 0.49 \\
\cline { 2 - 6 } & Corticated-Foliose & -0.09 & 0.91 & $\mathrm{~N} / \mathrm{S}$ & $\mathrm{N} / \mathrm{S}$ \\
\cline { 2 - 6 } & Leathery & 0.88 & 0.12 & $\mathbf{0 . 9 5}$ & $\mathbf{0 . 0 5}$ \\
\cline { 2 - 6 } & Articulated-Calcareous & $\mathbf{0 . 9 5}$ & $\mathbf{0 . 0 5}$ & $\mathbf{1 . 0 0}$ & $\mathbf{0 . 0 1}$ \\
\cline { 2 - 6 } & Crustose & 0.47 & 0.53 & 0.12 & 0.88 \\
\hline
\end{tabular}

Pearson correlation between abundance of macroalgal form-functional groups of field established communities with recruitment and succession tiles.

\section{Recruitment of coral reef macroalgal communities}

Of the 96 macroalgal species identified throughout the study, only five, Penicillus capitatus, Halimeda opuntia, H. tuna, Neomeris sp. and Spyridia clavata were found in field established communities and not recruited onto tiles (Appendix 1). The total numbers of species recruited were 38, 62 and 61 for sets I (Sep-Dec), Set II (Jan-Mar) and Set III (Mar-Jun) respectively. However, species richness averaged 8.48 per tile with no significant difference among seasons, the Rhodophyta phylum exhibited the highest species richness (Figure 5; Table 3, one-factor ANOVA, $\mathrm{F}=0.96, p=0.38)$. Among treatments, there was no significant differences in species richness, Margalef's or Shannon Heterogeneity indexes (one-factor ANOVA, F = $0.31, p=0.82 ; \mathrm{F}=1.18, p=0.32$ and $\mathrm{F}=0.70, p=0.55$ respectively).

Overall macroalgal abundance of recruitment tiles was similar before and after laboratory conditions, (two-factor ANOVA, $\mathrm{F}=0.01, p=0.95$ ). However, analysis of macroalgal abundances was completed using data from before laboratory conditions surveys. Percent cover of total macroalgae doubled from Set I (Sep-Dec) and Set II (Jan-Mar) with 56.1 \pm 28.7 and $49.4 \pm 30.1$ to Set III with 111.6 \pm 35.9 (Figure 6, two-factor ANOVA, F=39.35, $p=0.0001$ ). Overall percent 
cover of nutrient enrichment-exclusion treatment $(\mathrm{NE}=103.9 \pm 52.9)$ was higher compared with the other three treatments ranging between $62.9 \pm 31.2$ and $72.4 \pm 41.9$ (Figure 6 , two-factor ANOVA, $\mathrm{F}=8.78, p=0.001)$. No interaction between set and treatment was found in the twofactor ANOVA analysis $(\mathrm{F}=2.00, p=0.08)$.

Table 3. Diversity indexes by set of macroalgal species recruited on tiles. Letters indicate post-hoc (SNK) analysis when significant differences were found.

\begin{tabular}{|c|c|c|c|c|c|c|}
\hline \multirow{2}{*}{ Diversity Indexes } & \multicolumn{2}{|c|}{ Set I (Sep-Dec) } & \multicolumn{2}{c|}{ Set II (Jan-Mar) } & \multicolumn{2}{c|}{ Set III (Mar-Jun) } \\
\cline { 2 - 7 } & Mean & S.E. & Mean & S.E. & Mean & S.E. \\
\hline Richness (S) & 7.46 & 0.31 & 8.48 & 0.37 & 9.5 & 0.44 \\
\hline Margalef Diversity Index (d) & 1.67 & 0.07 & 1.99 & 0.18 & 1.99 & 0.11 \\
\hline Shannon Heterogeneity index (H') & $1.52(\mathrm{~B})$ & 0.05 & $1.23(\mathrm{~A})$ & 0.06 & $1.38(\mathrm{~B})$ & 0.07 \\
\hline
\end{tabular}

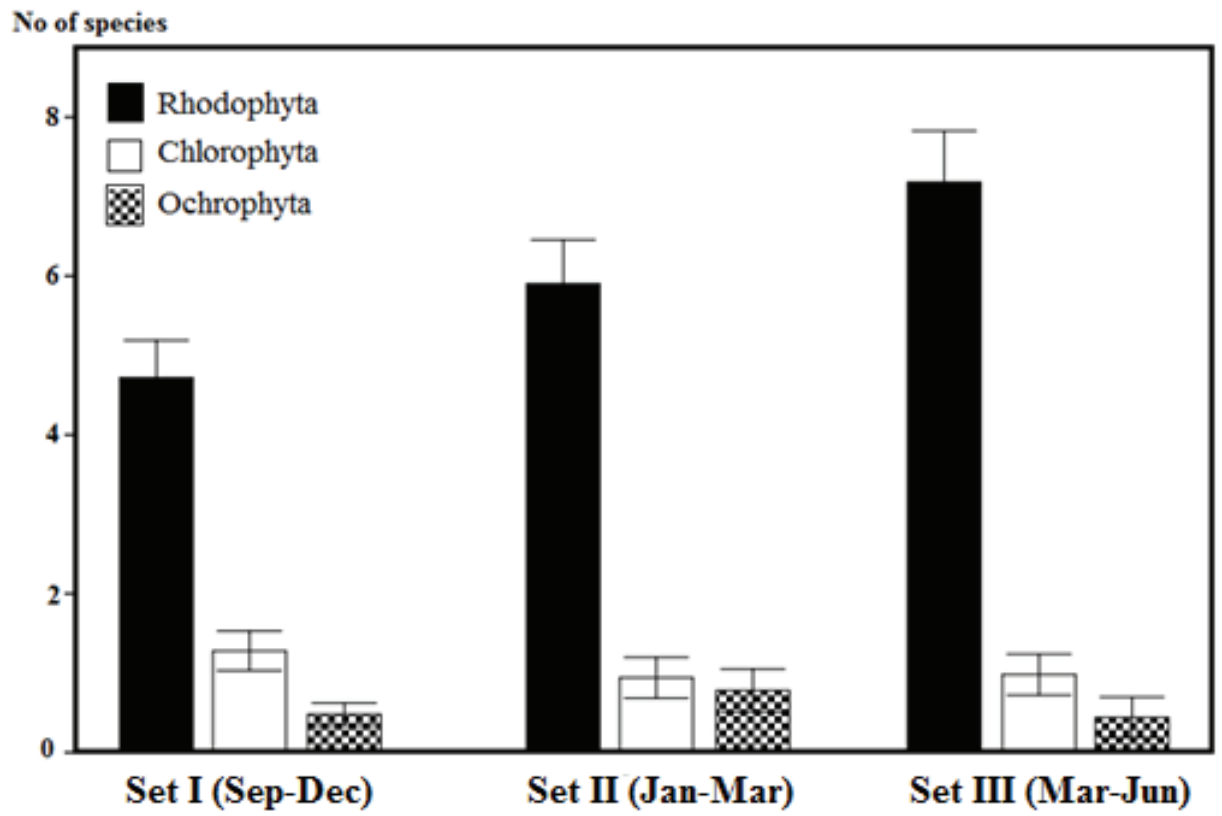

Figure 5. Average number of algal species found on recruitment tiles by phylum in each set. Bars represent standard error. 


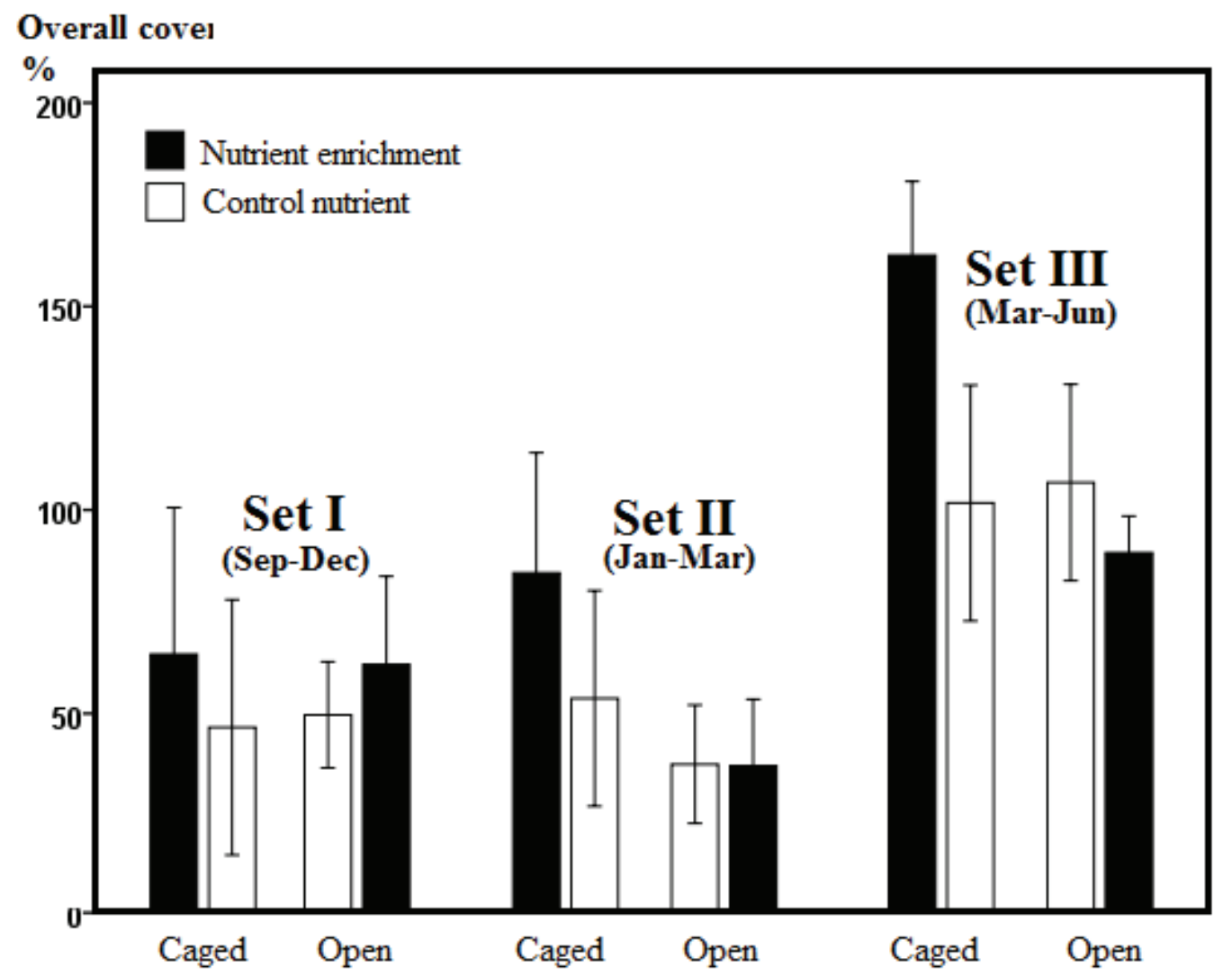

Figure 6. Total percent cover of macroalgal by treatments within each set of recruitment tiles. Bars represent standard error.

The non-metric Multidimensional Scaling analysis ran with abundance of all present species on recruitment tiles showed significant differences among seasons (Figure 7, ANOSIM, $\mathrm{R}=0.436, \quad p=0.001)$. Additionally, a similarity percentages-species contribution analysis (SIMPER) was performed to evaluate the effect of treatments on macroalgal communities of recruitment tiles (Table 4). Accordingly, only four taxa of algae, crustose coralline algae (CCA), Peyssonnelia sp., Jania capillacea and cyanobacteria were present throughout all treatments with some variation in their abundances (Table 4). 


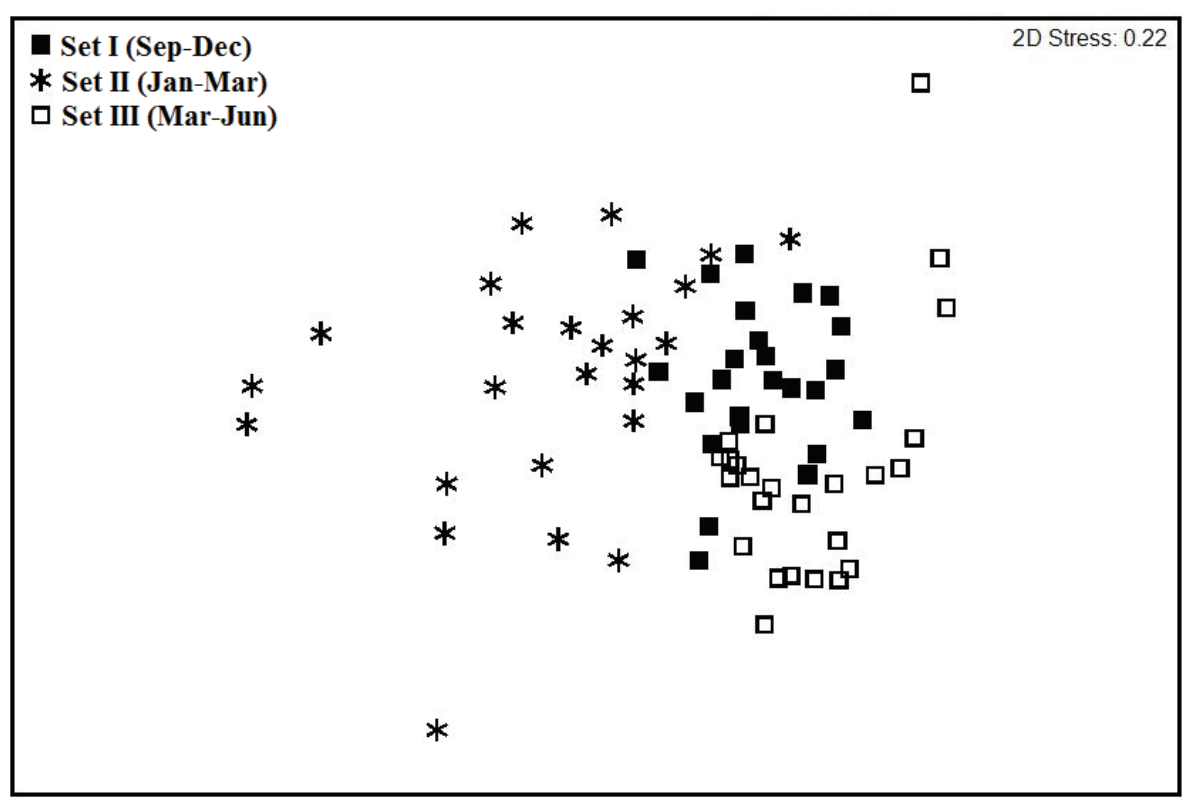

Figure 7. Non-metric Multidimensional Scaling analysis using abundance of all species of algae on recruitment tiles by set.

Table 4. Abundance and similarity percentage-species contribution to overall percent cover of recruitment tiles of most common species (species that cover at least $90 \%$ ) by treatments. Data calculated using SIMPER analysis from PRIMER 6. Asterisks indicate most common species by sets.

\begin{tabular}{|c|c|c|c|c|c|c|c|c|c|c|}
\hline \multirow[t]{2}{*}{ Species } & \multicolumn{2}{|c|}{$\begin{array}{c}\text { Nutrient } \\
\text { enrichment- } \\
\text { Exclusion (NE) }\end{array}$} & \multicolumn{2}{|c|}{$\begin{array}{c}\text { Control-Exclusion } \\
\text { (CE) }\end{array}$} & \multicolumn{2}{|c|}{$\begin{array}{l}\text { Control-Open } \\
\text { (CO) }\end{array}$} & \multicolumn{2}{|c|}{$\begin{array}{c}\text { Nutrient } \\
\text { enrichment-Open } \\
\text { (NO) }\end{array}$} & \multicolumn{2}{|c|}{ Statistical sign. } \\
\hline & Mean & SE & Mean & SE & Mean & SE & Mean & SE & $\mathbf{F}$ & $\mathbf{p}$ \\
\hline Jania capillacea & 19.80 & 6.64 & $4.67 *$ & 2.63 & 1.17 & 0.85 & $2.17^{*}$ & 0.63 & $\mathrm{~N} / \mathrm{A}$ & 0.002 \\
\hline Crustose coralline algae & $5.78^{*}$ & 1.46 & $8.25^{*}$ & 4.86 & $7.09 *$ & 1.71 & $11.28 *$ & 2.55 & 0.887 & 0.453 \\
\hline Peyssonnelia spp. & $4.70^{*}$ & 1.32 & $8.42^{*}$ & 2.43 & $10.30^{*}$ & 1.83 & $11.8^{*}$ & 2.21 & 2.357 & 0.080 \\
\hline Cyanobacteria & $9.73 *$ & 3.89 & $9.25^{*}$ & 3.56 & $21.08^{*}$ & 5.81 & $18.21^{*}$ & 4.86 & $\mathrm{~N} / \mathrm{A}$ & 0.322 \\
\hline Ectocarpus sp. & $7.33^{*}$ & 3.58 & 4.33 & 3.31 & 3.41 & 2.90 & 2.54 & 2.08 & 0.719 & 0.544 \\
\hline Hypnea spinella & $4.33^{*}$ & 1.82 & 1.33 & 1.25 & 1.77 & 0.64 & 1.81 & 1.06 & N/A & 0.642 \\
\hline Jania adhaerens & $6.00^{*}$ & 3.53 & 0.50 & 0.42 & 0.09 & 0.06 & 0.67 & 0.46 & $\mathrm{~N} / \mathrm{A}$ & 0.475 \\
\hline Amphiroa fragilissima & $9.00 *$ & 5.03 & 0.33 & 0.33 & 0.28 & 0.21 & 0.00 & 0.00 & N/A & 0.150 \\
\hline Hypnea valentiae & $5.00 *$ & 2.88 & 1.66 & 1.12 & 0.90 & 0.65 & 0.54 & 0.42 & N/A & 0.502 \\
\hline Sargassum sp. & 1.94 & 0.91 & $6.38 *$ & 3.36 & 0.05 & 0.03 & 0.01 & 0.00 & $\mathrm{~N} / \mathrm{A}$ & 0.001 \\
\hline Laurencia cervicornis & 2.47 & 1.99 & $5.25^{*}$ & 2.57 & $5.08^{*}$ & 2.03 & 0.23 & 0.08 & $\mathrm{~N} / \mathrm{A}$ & 0.001 \\
\hline Laurencia intricata & 0.67 & 0.67 & $3.83^{*}$ & 2.22 & 0.73 & 0.34 & 0.50 & 0.29 & $\mathrm{~N} / \mathrm{A}$ & 0.289 \\
\hline Polysiphonia sp. 1 & 1.00 & 1.00 & $1.33^{*}$ & 0.64 & 0.35 & 0.21 & 0.42 & 0.42 & $\mathrm{~N} / \mathrm{A}$ & 0.173 \\
\hline Heterosiphonia gibbesi & 1.33 & 1.03 & 0.08 & 0.08 & $1.50 *$ & 0.56 & 0.00 & 0.00 & N/A & 0.029 \\
\hline Average Simililarity & \multicolumn{2}{|c|}{18.04} & \multicolumn{2}{|c|}{19.14} & \multicolumn{2}{|c|}{25.13} & \multicolumn{2}{|c|}{27.00} & & \\
\hline
\end{tabular}

The non-metric Multidimensional Scaling used to analyze treatment effects on macroalgal cover of recruitment tiles revealed a clear treatment pattern for all sets together, Set I and II (Figure 8, ANOSIM R=0.11, $p=0.003 ; \mathrm{R} .0 .33, p=0.002 ; \mathrm{R}=0.48, p=0.001$ respectively). Contrarily, neither statistical differences nor clear pattern among treatments were found for Set II (Figure 8, ANOSIM R=0.03, $p=0.700$ ). 


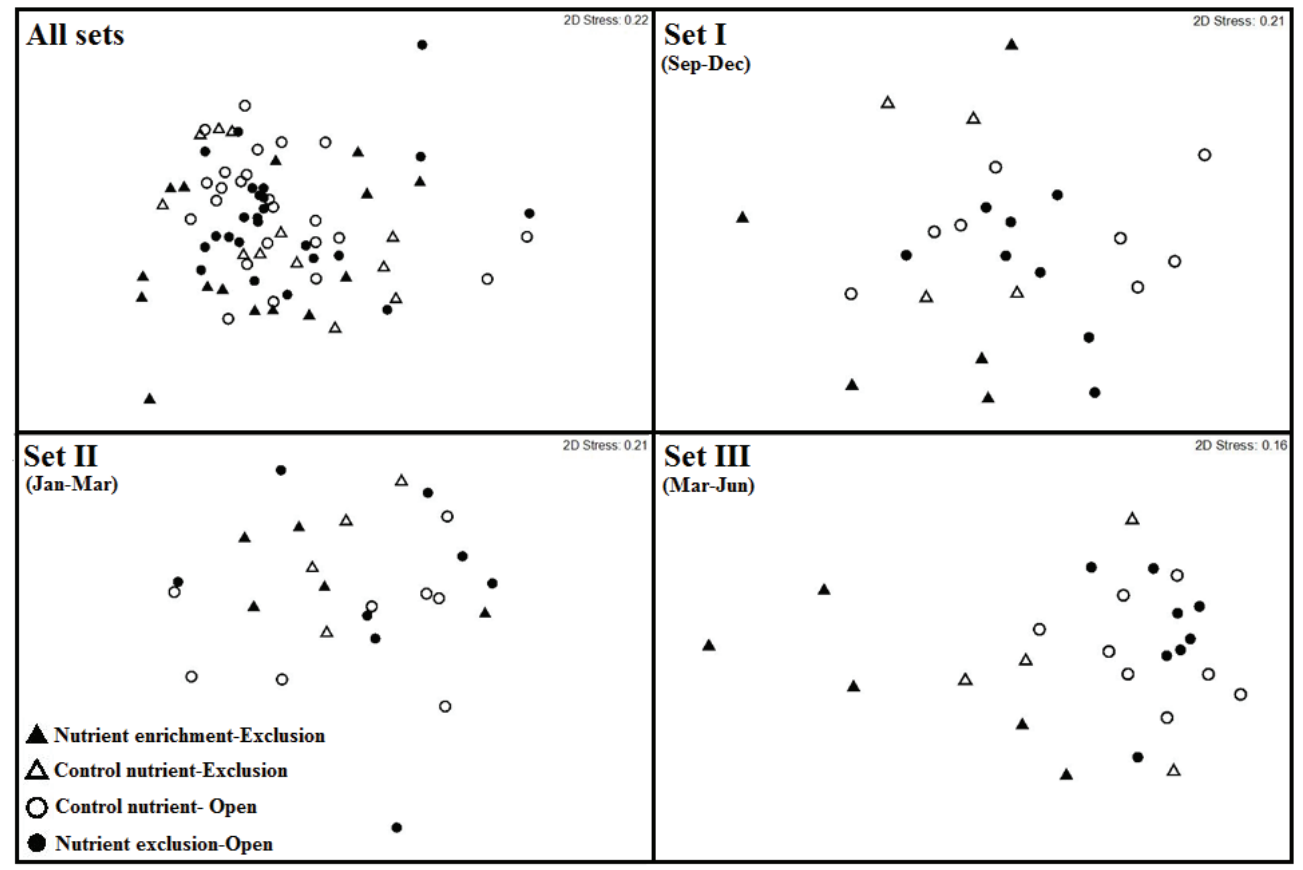

Figure 8. Non-metric Multidimensional Scaling analysis among treatments including abundance of all algal species found on recruitment tiles, for all sets together and set I, II, and III separately.

\section{Succession of coral reef macroalgal communities}

Overall macroalgal percent cover of succession tiles doubled by June, $62.4 \pm 5.8$, compared to January with $31.5 \pm 5.3$ for all treatments (Figure 9, three-factor ANOVA, F=24.02, $p=0.001)$. In both January and June, abundance was significantly higher when herbivores were excluded in both control and nutrient enriched treatments (Figure 9, three-factor ANOVA, $\mathrm{F}=32.72, p=0.001$ ) but no effects of nutrient enriched treatments were found (Figure 9, threefactor ANOVA, $\mathrm{F}=0.482, p=0.491$ ). The abundance of filamentous algae in June (average 35.8 \pm 3.8 ) was twice as high as January, 16.4 \pm 3.4 (Figure 9, three-factor ANOVA, F=11.33, $p=0.002$ ). Percent cover of filamentous algae was negatively affected by nutrient availability having enriched nutrient treatments lower abundance compared to ambient treatments (threefactor ANOVA, $\mathrm{F}=9.81, p=0.003)$. No effects related with herbivory level were found on filamentous algae cover of succession tiles (three-factor ANOVA, $\mathrm{F}=0.040, p=0.843$ ). 

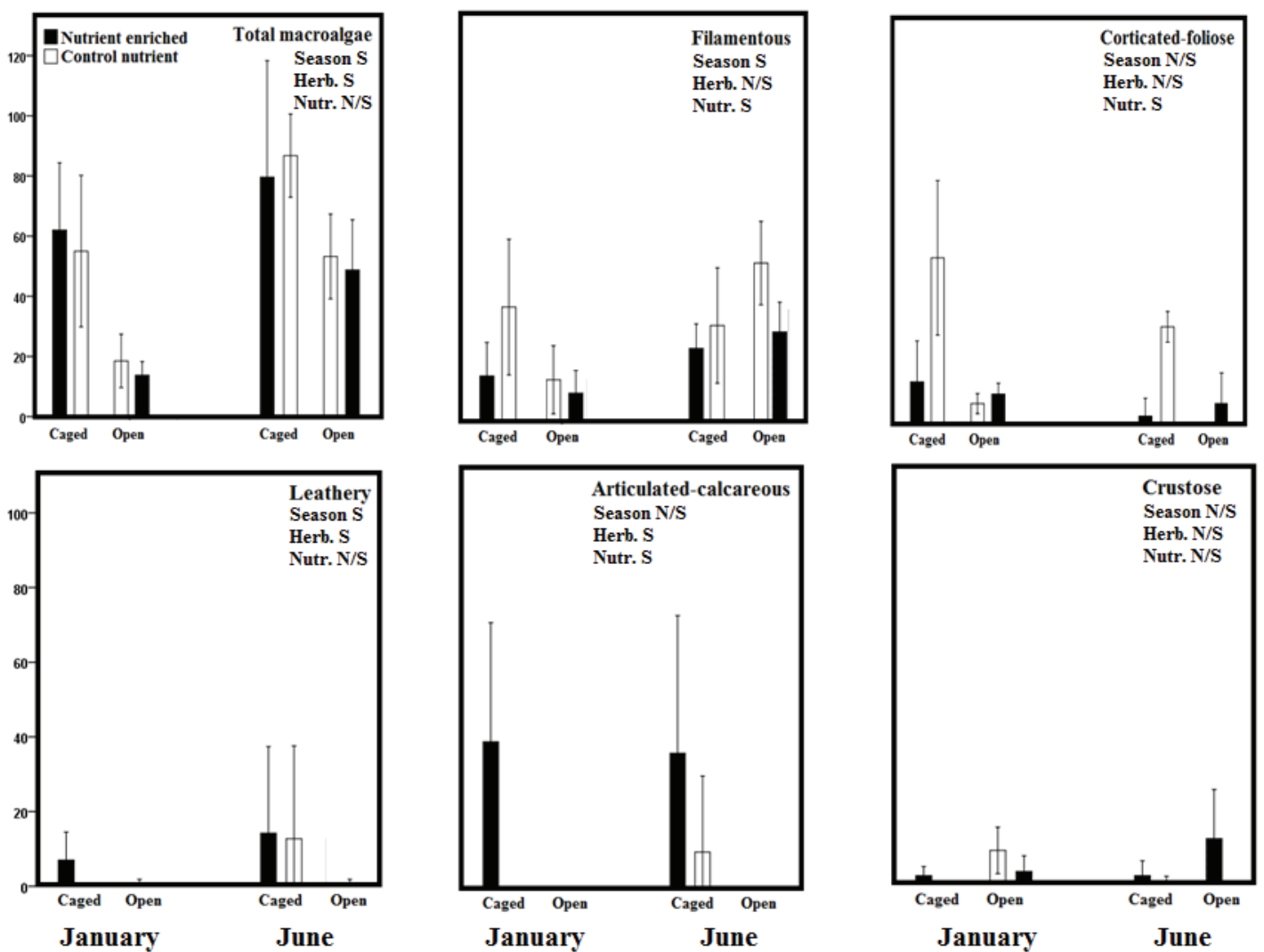

Figure 9. Abundance of macroalgal form-functional group on succession tiles by treatment in January and June. Whiskers represent standard errors. Statistical significant of analyzed variables, season, herbivores and nutrient, are indicated by $\mathrm{S}$ (significant) and N/S (no significant).

Conversely to filamentous algae, corticated-foliose macroalgae (e.g., Dictyota spp.), was $17.7 \pm 4.0 \%$ in January compared to June (average $7.2 \pm 2.4$ ) with no significant differences (threefactor ANOVA F=3.77, $p=0.06$ ). No effects of herbivore exclusion were observed (three-factor ANOVA $\mathrm{F}=2.1, p=0.15$ ) while nutrient enrichment treatments depleted percent cover of corticated-foliose within cages (Figure 9, three-factor ANOVA F=5.5, $p=0.03$ ). Leathery macroalgae were mainly represented by Turbinaria turbinata and Sargassum sp., while articulated calcareous were mostly specimens of Amphiroa spp. and Jania spp. Leathery and articulated calcareous were present only when herbivorous fish were excluded (Figure 9, Kruskal Wallis, $p=0.001, p=0.001$ respectively). Percent cover of articulated calcareous was higher in nutrient enriched treatments (Figure 9, Kruskal Wallis, $p=0.02$ ). Conversely, nutrient or 
herbivores exclusion had no effect on crustose algae (e.g., Peyssonnelia spp. and crustose coralline algae) average of $4.3 \pm 1.3$, at any season (Figure 9, Kruskal Wallis, $p=0.11, p=0.6$ respectively).

In the fourth month, (January) percent cover of overall macroalgae on succession tiles was higher within caged treatments compared to open treatments (Figure 10, one-factor ANOVA $\mathrm{F}=10.80, p=0.001)$. Filamentous and corticated-foliose covered part of all four treatments, where leathery and articulated calcareous were only present within nutrient enriched treatment (Figure 9). Crustose coralline algae covered less that $10 \%$ only in open treatments. By the ninth month (June), percent cover of filamentous algae increased in all treatments while leathery and calcareous-articulated increased in abundance within both caged treatments (Figure, 10). The abundance of corticated-foliose (e.g., Dictyota sp) decreased through time within cage enriched with nutrient. Approximately $50 \%$ of empty spaces in open areas (uncaged treatments) persisted nine months after tiles were placed on the reef (Figure 10). When open areas were nutrient enriched, the total abundance did not increase, and differently to control treatment, crustose and corticated-foliose algae covered part of the tiles (Figure 10).

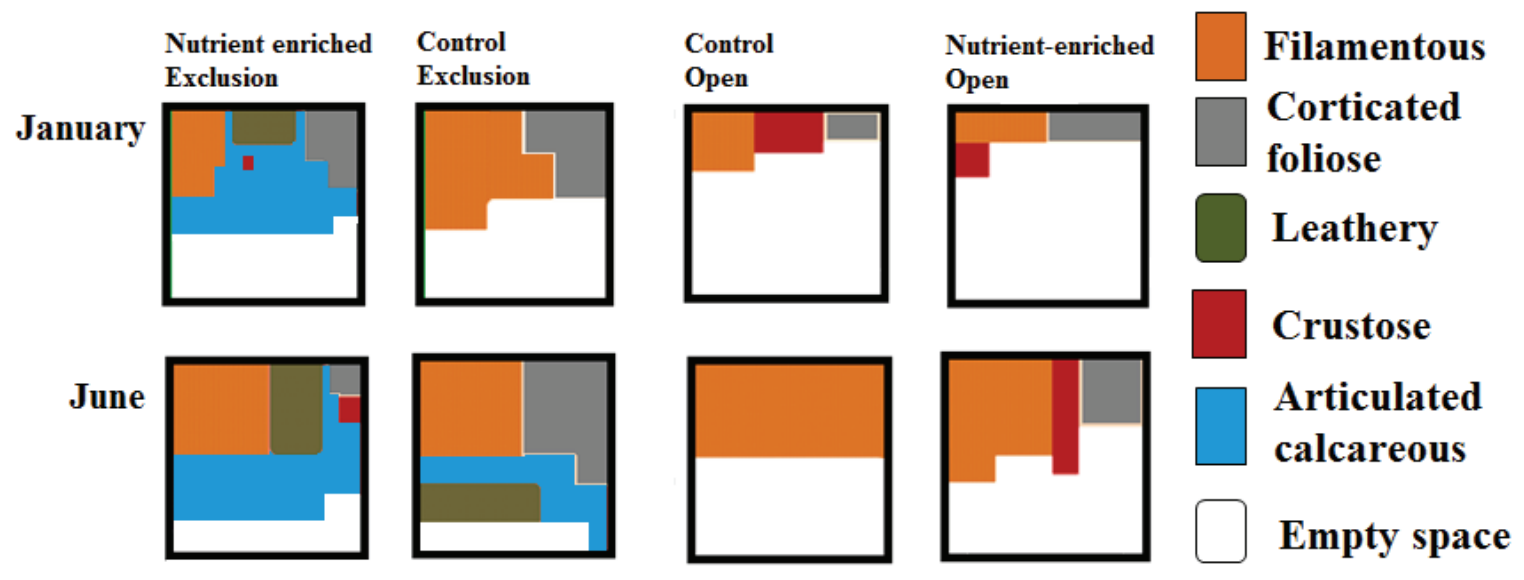

Figure 10. Graphical representation of macroalgal succession on permanent tiles by treatment. Size of colors represent mean of percent cover of macroalgal form-functional groups. 
To estimate the impact of different treatments on macroalgal, a MDS was run including abundance of all macroalgal form-functional groups on permanent tiles from each survey time, January and June. In January the MDS separated nutrient enrichment-exclusion from the other three treatments (Figure 11, ANOSIM, $\mathrm{R}=0.19, p=0.02$ ). Whereas, by June, nutrient enrichmentexclusion treatment and control nutrient-exclusion treatments seem to differ from open treatments (Figure 11, ANOSIM, $\mathrm{R}=0.46, p=0.01$ ).

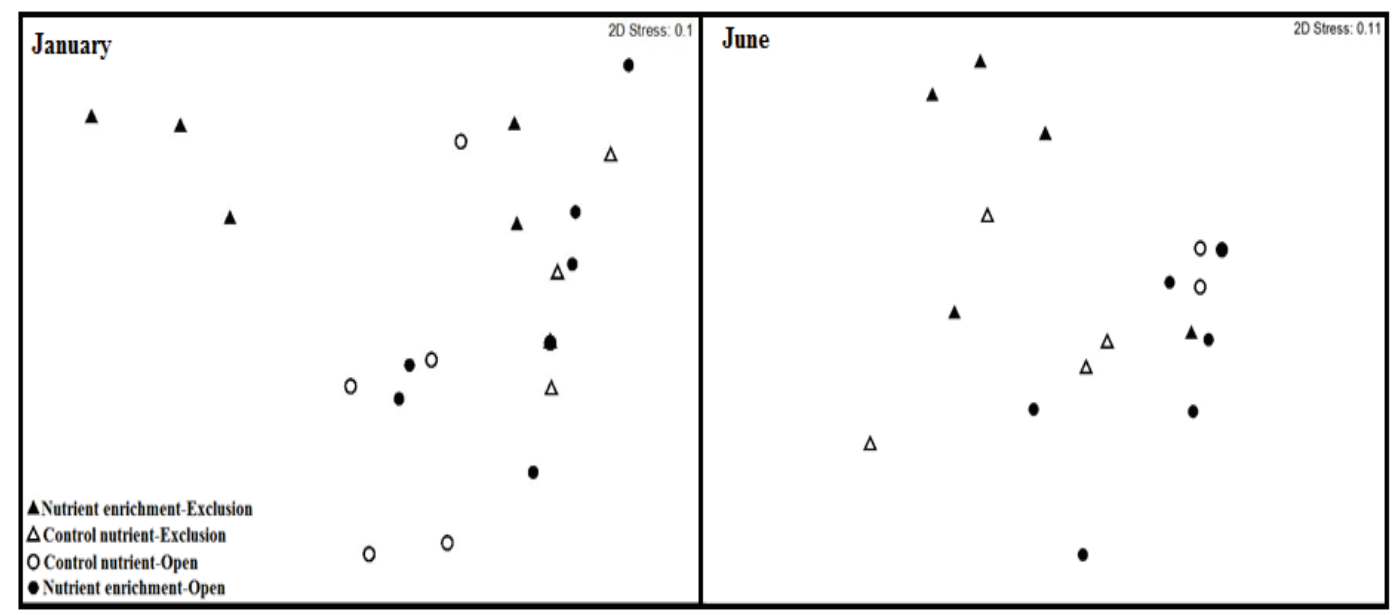

Figure 11. Non-metric Multidimensional Scaling analysis by treatment including abundance of all macroalgal form-functional group on succession tiles in January and June

\section{4 Discussion}

The magnitude of the effects of nutrient availability and herbivore pressure on controlling macroalgal abundance varied with community successional stage. While both bottom-up (nutrient availability) and top-down (herbivory pressure) drivers were important at earlysuccessional stages, only top-down (fish grazing) remained determinant at late-successional stages. In addition, total abundance and FFG composition of field established communities within quadrats, was similar to macroalgal communities of recruitment and succession tiles, 
suggesting that adult coral reef macroalgal communities could play an important role regulating recruitment via propagule supply.

\section{Fish community structure and nutrient levels of the study site}

The experimental site presented a high density and biomass of herbivorous fish compared to other Caribbean reefs such as Guanacahabibes National Park, Cuba and Virgin Islands Coral Reef Monument (Claro and Cantelar, 2003; Nemeth et al., 2003; Lang and Ginsburg, 2006). In addition, higher DIN and SRP in water content and lower C:N ratio in Dictyota sp. tissue evidenced higher availability and uptake of nitrogen in nutrient enriched treatments. In fact, similar results have been found by other authors where nutrient enrichment of marine systems has led to rapid uptake of nitrogen and consequently decrease of $\mathrm{C}: \mathrm{N}$ ratio (Ferdie and Fourqurean, 2004; Littler et al., 2010). Thus, the experimental setting could be considered operative and reliable.

Analyses of total macroalgae abundance of established communities across the study period showed a clear increase towards spring season (June). Comparable seasonal patterns have been reported for other Caribbean reefs such as Glover Reef Atoll, Belize and Puerto Rico (Ruiz and Ballantine, 2009; Ferrari et al., 2012). Three macroalgal form-functional groups, filamentous, calcareous articulated and crustose coralline algae were the major components of summer seasonal increase which could be related with higher water temperature and light availability (Tsai et al., 2005; Ferrari et al., 2012). In the case of corticated-foliose algae (e.g., Dictyota sp.) abundance decreased towards June (spring/summer). Since corticated-foliose algae presented higher abundance in open treatments in January, the decrease of percent cover could be caused by increased grazing rate in spring-summer season. It has been demonstrated that parrotfish and surgeonfish, increase their grazing frequency during wet (spring-summer) season 
(Smith, 2008; Duran and Claro, 2009). However, herbivory studies completed in Floridian coral reefs have shown reduction of abundance of Dictyota sp. in areas grazed by herbivorous fish (Burkepile and Hay, 2006; Burkepile and Hay, 2008; Sotka and Hay, 2009). On the other hand, Lirman and Biber (2000) reported abundance peak of Dictyota sp. in July-August covering 57 \% of coral reef at northern Florida Reef Tract. According to Lirman and Biber (2000), growth rate and monopolization of Dictyota sp. at their site are consequence of insufficiently control of herbivores. In addition, seasonal variation in abundance of Dictyota sp. could be related with water temperature and light availability rather than herbivory consumption (Ferrari et al., 2012).

Significant higher abundance of total macroalgae of field established communities within caged treatments supports the hypothesis that herbivory is a major driver of reef macroalgal assemblages (Lewis, 1986). Substantial evidences of herbivores exclusion treatment showing strong effects on controlling reef macroalgal assemblages could be found in multiple recent scientific studies (Burkepile and Hay, 2009; Sotka and Hay, 2009; Rasher et al., 2012). Furthermore, herbivore pressure could also regulate macroalgal interspecific competition. In fact, when herbivorous were excluded, abundance of leathery and calcareous articulated macroalgae (late successional species) increased while corticated-foliose decreased. Contrarily to herbivory, no effects of nutrient enrichment treatments on total macroalgal abundance field established communities were observed indicating that nutrient loading did not exert major control of adult macroalgal assemblages at the study site. According to Smith et al., (2010) effects of nutrient loading on coral reef macroalgae become tangible after three to four months of releasing nutrients but the current study was started after for two years of steadily nutrient release at the experimental site. Therefore, the study time period should be long enough to notice any effect of nutrient enrichment on macroalgae within experimental setting. On the other hand, similarities 
(correlations) of community composition at FFG across different successional stages, recruitment tiles, succession tiles and field established communities could be taken as the first evidence of adult macroalgal community acting as propagule supply on coral reefs.

\section{Recruitment of coral reef macroalgal communities}

It was found a seasonal recruitment marked by differential species composition and abundances on recruitment tiles across sets. Indeed, cover of algae was higher in Set III (MarJun, spring season). Total number of species was higher in Sets II and III. However, only Rhodophyta species number increase towards Set III. It is well documented that some red macroalgal species (Laurencia $\mathrm{sp}$. and Gracilaria sp.) have a reproductive peak towards summer season triggered by warmer water temperature (Tsai et al., 2005). Nevertheless, less reproduction between March-June of unidentified species of Gracilaria has been also reported (Hay and Norris, 1984). However, a different experimental design and metrics could be useful to address the topic such as examination of reproductive tissue in multiple macroalgal species and potential responses to ambient factors (light, nutrient availability and temperature). In addition, reduction of herbivory and nutrient loading combined (Nutrient enrichment-Exclusion) was the only treatment showing effects on abundance of macroalgae on recruitment tiles. Particularly, nutrient loading could enhance germination and increase growth rate of new arrival and overwinter propagules (Cecere et al., 2011). Therefore, the combination of denser propagule areas and nutrient loading could override grazing rate and consequently increase abundance of macroalgae (Worm et al., 1999). However, such situations have been mostly reported for fast-growing species of macroalgal such as Ulva spp., Cladophora sp., Polysiphonia sp. and Ceramium sp. (Worm and Lotze, 2006; Karez et al., 2004; Imchen, 2012). Importantly, in coral reefs, 
abundance of macroalgal recruits could also be related with type of substrate, herbivory and nutrient availability (Diaz-Pulido and McCook, 2002, 2003, 2004).

\section{Succession of coral reef macroalgal communities}

Succession patterns are expect to follow a replacement of early stages species such as filamentous turf (e.g., Enteromorpha sp. Ceramium sp., Felmania sp.) by late successional species such as leathery and calcareous articulated. Results of this study show that succession was affected by nutrient enrichment treatment that significantly increased percent cover of articulated-calcareous macroalgae but only in succession tiles when herbivorous were excluded, and not on field established communities. Thus, it is thought that the magnitude of nutrient availability effects reduces towards late successional stages and it is noticed only when herbivory pressure is reduced or absent. For instance, after nine months, late succession species of macroalgae (e.g., Sargassum sp. and Amphiroa sp.) were present only on succession tiles placed within cages with and without nutrient enrichment. Contrarily, both open nutrient enriched and open control treatments, still mostly covered by early successional species after nine experimental months (e.g., filamentous turf). Thus, both nutrient availability and herbivory were significant drivers at early successional stages whereas only herbivory showed significant effects of macroalgal abundance towards later successional stages. 


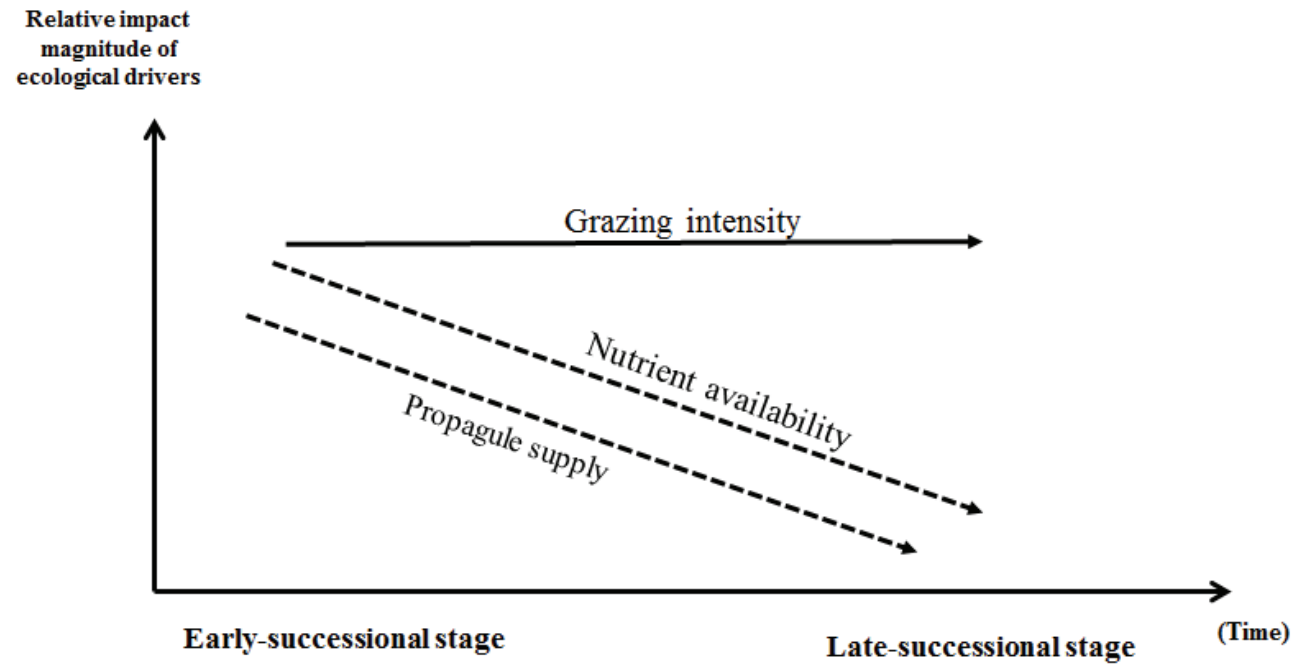

Figure 12. Schematic representation of magnitude effects of grazing intensity, nutrient availability and propagule effects on recruitment and succession of coral reef macroalgal communities. Propagule supply, grazing intensity and nutrient availability are determinant at early succession stages. Towards late successional stages, grazing intensity (solid line) remains constant while impact magnitude of nutrient availability and propagule supply (dashed lines) decrease.

Furthermore, macroalgal cover of different form-functional groups onto succession tiles varied with treatments which suggest treatments effects on interspecific macroalgal competition. For instance, abundance of calcareous articulated and leathery species increased in June while corticated-foliose (e.g., Dictyota sp.) decreased. Similar results were found by Hixon and Bostroff (1996) where removal of grazers led to a rapid shift from green and brown filaments to finely branched filaments and succeed by blades and coarsely thick filaments. Macroalgal species of late successional stages such as leathery (e.g., Sargassum spp. and Turbinaria spp.) and calcareous articulated (e.g., Amphiroa spp., Halimeda spp. and Jania spp.) are well known to be consumed by coral reef grazers (Lobel and Ogden, 1981; Hoey and Bellwood, 2010). However, their resistance to herbivory has been also suggested (Littler et al. 1983; Steneck and Dethier, 1994). Current results support the hypothesis that high abundance and diversity of herbivorous fish can control growth rate of late-successional macroalgal species and 
consequently increase coral reef resilience (Burkepile and Hay, 2011). Additionally, some successional trajectories (pathways) of coral reef macroalgal assemblages have been proposed where abundances and species composition of different successional stage species vary depending upon predominant herbivore groups (Sammarco, 1983; Hixon and Bostroff, 1996). For instance, Ceccarelli et al. (2011) described damselfish species (Pomacentridae) capable of decelerating successional rate by keeping macroalgal assemblages dominated by palatable filamentous algae species. At the present experimental study site no differences of damselfish density among treatments were found (pers. observations) so it is likely that damselfish would not affect results of studied macroalgal succession in our site. Also, McClanahan (1997) reported dominance of early-succession filamentous species over 450 day period for highly sea-urchin populated coral reefs. Nevertheless, at the current studied site only a single individual long-spiny sea-urchin (Diadema antillarum) was observed during the entire study period (September 2011 July 2012). Therefore, macroalgal successional patterns of present study are mostly influenced by fish grazers (Scaridae and Acanthuridae) and nutrient loading effects. Ultimately, results of present study have some important implications in terms of coral reef ecosystem functioning. Mumby and Steneck (2008) described two ecosystem process feedbacks, positive and negative, depending upon grazing intensity. In that sense, present study supports the hypothesis of high grazing rate as primary ecological driver or positive process feedback at late-successional stage. By controlling abundance of late-successional species, larger and more structural complex species, and increasing abundance of crustose algae, herbivores fish could indirectly enhance coral recruitment. It has been shown that coral larvae preferentially settle on crustose coralline algae while fleshy algae inhibit coral recruitment (Harrington et al., 2004; Ritson-Williams et al., 2009). Additionally, coral reef macroalgal overgrowths usually proceed after natural 
disturbances such as hurricanes or coral bleaching events (Gardner et al., 2005; Diaz-Pulido and McCook, 2002), where new substrate is available to be colonized. Thus, higher abundance of mature macroalgal prevailing right after disturbances would provide propagules and consequently facilitate algal overgrowths. In addition, coral depauperate reefs as a consequence of storm and physical damages that constantly provide new substrate for algal recruitment might be the most vulnerable sites to detrimental effects of high nutrient levels. Therefore, I recommend to managers to support policies that will result in reduction of nutrient and increase grazers in order to reinforce resilience of coral reef ecosystems.

\section{References}

Bohnsack, J. A. and D. E. Harper. 1988. Length-weight relationships of selected marine reef fishes from southeastern United States and the Caribbean. NOAA Tech. Mem. NMFSSEFC-215. $31 \mathrm{p}$.

Bolser, R. C. and M. E. Hay. 1996. Are tropical plants better defended? Palability and defenses of temperate vs. tropical seasweeds. Ecology. 77 (8): 2269-2286.

Boyer, K. E., P. Fong, A. R. Armitage and R. A. Cohen. 2004. Elevated nutrient content of tropical macroalgae increases rates of herbivory in coral, seagrass, and mangrove habitats. Coral Reefs. 23: 530-538.

Bracken, M. E. S. and K. J. Nielsen. 2004. Diversity of intertidal macroalgae increases with nitrogen loading by invertebrates. Ecology. 85 (10): 2828-2836. Atoll. Res. Bull 496: 566-589.

Burkepile, D. and M. E. Hay. 2006. Herbivore VS nutrient control of marine primary producers: context-dependent effects. Ecology, 87(12):3128-3139.

Burkepile, D. and M. E. Hay. 2008. Herbivore species richness and feeding complementarity affect community structure and function on a coral reef. PNAS. www.pnas.org/cgi/content/full/ 0801946105/DCupplemental.

Burkepile, D. and M. E. Hay. 2009. Nutrient versus herbivore control of macroalgal community development and coral growth on a Caribbean reef. Mar. Ecol. Prog. Ser. 389: 71-84.

Burkepile, D. and M. E. Hay. 2010. Impact of herbivore identity on algal succession and coral growth on a Caribbean Reef. PLoS ONE. 5(1):e8963.doi:10.1371/journal.pone.0008963. 
Burkepile, D. E. and M. E. Hay. 2011. Feeding complementary versus redundancy among herbivores fishes on a Caribbean reef. Coral Reefs. 30:351-362.

Callow, M. E., J. A. Callow, J. D. Pickett and R. Wetherbee. 1997. Primary adhesion of Enteromorpha (Chlorophyta, Ulvales) propagules: quantitative settlement studies and video microscopy. J. Phycol. 33: 938-947.

Carpenter, R. C. 1986. Partitioning herbivory and its effects on coral reef algal communities. Ecological Monograph. 56 (4): 345-363.

Ceccarelli, D. M., G. P. Jones and L. J. McCook. 2011. Interactions between herbivorous fish guilds and their influence on algal succession on a coastal coral reef. Journal of experimental marine biology and ecology. 399: 60-67.

Cecere, E., A. Petrocelli and M. Verlaque. 2011. Vegetative reproduction by multicellular propagules in Rhodophyta: an overview. Marine Ecology. 32: 419-437.

Claro, R. and K. Cantelar. 2003. Rapid assessment of the coral communities of María La Gorda, Southeast Ensenadade Corrientes, Cuba (Part 2: reef fishes). Atoll. Res. Bull 496: 278293.

Clifton, K. E. 2008. Spatial patterns of reproductive synchrony by four genera of tropical Green seaweed across a latitudinal gradient in the Caribbean. Proceedings of th $11^{\text {th }}$ International coral Reef Symposium, Ft. Lauderdale, Florida. Session 11: 351-355.

Collado-Vides, L., V. Mazzei, T. thyberg and D. Lirman. 2011. Spatio-temporal patterns and nutrients status of macroalgae in a heavily managed region of Biscayne Bay, Florida, USA. Botanica Marine. 54: 377-390.

Dawes, C. J. 1998. Biotic factors, Chapter 3, In Marine Botany $2^{\text {nd }}$ Edition. John Wiley and Sons, Inc: $480 \mathrm{pp}$.

Dawes, J. C. and A. C. Mathieson. 2008. The seaweeds of Florida. University Press of Florida, Gainesville. 591 pp.

Diaz-Pulido, G. and L. J. McCook. 2002. The fate of bleach corals: Patterns and dynamics of algal recruitment. Mar. Ecol. Prog. Ser. 232: 115-128.

Diaz-Pulido, G. and L. J. McCook. 2003. Relative roles of herbivory and nutrients in the recruitment of coral reef seaweeds. Ecology. 84 (8): 2026-2033.

Diaz-Pulido, G. and L. J. McCook. 2004. Effects on live coral, epilithic algal communities and substrate type on algal recruitment. Coral Reefs. 23: 225-233.

Duarte, C. M. 1992. Nutrient concentration of aquatic plants: Patterns across species. Limnol. Oceanogr. 37 (4): 882-889. 
Duran, A. and R. Claro. 2009. The feeding activity of herbivorous fishes and their impact on coral reefs with different levels of anthropogenic degradation. Rev. Biol. Trop. 57 (3): 687-697.

Ferdie, M. and J. W. Fourqrean. 2004. Responses of seagrass communities to fertilization along a gradient of relative availability of nitrogen and phosphorus in a carbonate environment. Limnol. Oceanogr. 49 (6): 2082-2094.

Ferrari, R., M. Gonzalez-Rivero, J. C. Ortiz and P. J. Mumby. 2012. Interaction of herbivory and seasonality on the dynamics of Caribbean macroalgae. Coral Reefs. 31 (3): 683-692.

Fong, P., K. E. Boyer, K. Kamer and K. A. Boyle. 2003. Influence of initial tissue nutrient status of tropical marine algae on response to nitrogen and phosphorus additions. Mar. Ecol. Prog. Ser. 262: 111-123.

Fong, P., K. Kramer, K. E. Boyer and K. A. Boyle. 2001. Nutrient content of macroalgae with differeing morphologies may indicate sources of nutrients for tropical marine systems. Mar. Ecol. Prog. Ser. 220: 137-152.

Foster, M. S. 1975. Algal succession in a Macrosystis pyrifera forest. Marine Biology. 32: 313329.

Fourqurean, J. W., J. C. Zieman and G. V. N. Powell. 1992. Phosphorus limitation of primary production in Florida Bay: Evidence from C:N:P ratios of the dominant seagrass Thalassia testudinum. Limnol. Oceanogr. 37(1): 162-171.

Fourqurean, J. W., J. C. Zieman and G. V. N. Powell. 2002. Phosphorus limitation of primary production in Florida Bay: Evidence from $\mathrm{C}: \mathrm{N}: \mathrm{P}$ ratios of the dominant seagrass Thalassia testudinum. Limnology and Oceanography 37:162-171.

Gardner, T. A., I. M. Cote, J. A. Gill, A. Grant and A. R. Watkinson. 2005. Hurricanes and Caribbean coral reefs: impacts, recovery patterns, and role in long term decline. Ecology. 86 (1): 174-184.

Greene, C. H., H. Schoener and E. Corets. 1983. Succession on marine hard substrata: the adaptive significance of solitary and colonial strategies in temperate fouling communities. Mar. Ecol. Prog. Ser. 13: 121-129.

Grime, J. P. 1979. Plant strategies and vegetation processes. Great Britain at The Pritman Press: $222 \mathrm{pp}$.

Guimaraens, M. A., J. A. M. da Silva and D. Falcao. 2011. Temporal variability in macroalgae recruitment and succession on sandstone reefs ar Piedade Beach - PE, Brazil. Neotropical Biology and Conservation. 6 (3): 170-177. 
Harrington, L., K. Fabricius. G. De Ath and A. Negri. 2004. Recognition and selection of settlement substrata determine post-settlement survival in corals. Ecology. 85 (12): 34283437.

Hay, M. 1984. Patterns of fish and urchin grazing on Caribbean coral reefs: are previous results typical? Ecology. 65 (2): 446-454.

Hay, M. E. and J. N. Norris. 1984. Seasonal reproduction and abundance of six sympatric species of Gracilaria Grev. (Gracilariaceae; Rodhophyta) on a Caribbean subtidal sand plain. Hydrobiologia. 116/117: 63-94.

Hay, M. E., W. Fenical. and K. Gustafson. 1987. Chemical Defense Against Diverse Coral Reef Herbivores. Ecology, 68 (6): 1581- 1591.

Hill, M. F., J. D. Witman and H. Caswell. 2004. Markov chain analysis of succession in a rockery community. The American naturalist. 164 (2): E46-E61.

Hixon, M. A. and W. N. Brostoff. 1996. Succession and herbivory: effects of differential fish grazing on Hawaiian coral-reef algae. Ecological Monograph. 66(1): 67-90.

Hoey, A. S. and D. R. Bellwood. 2011. Suppression of herbivory by macroalgal density. A critical feedback on coral reefs ? Ecology Letters. $14: 267-273$.

Hughes, T. P. 1994. Catastrophes, phase shifts, and large-scale degradation of a Caribbean coral reef. Science 265: 1547-1551.

Hughes, T. P; A. M. Szmant; R. Steneck; R. Carpenter and S. Miller. 1999. Algal blooms on coral reefs: What are the causes? Limnol. Oceanogr. 44(6): 1583-1586.

Imchen, T. 2012. Recruitment Potential of a Green Alga Ulva flexuosa Wulfen Dark Preserved Zoospore and Its Development. PLoS ONE 7(3): e32651. doi:10.1371/journal.pone.0032651.

Kares, R., S. Engelbert, P. Kraufvelin, M. F. Pedersen and U. Sommer. 2004. Biomass response and change in composition of ephemeral macroalgal assemblages along an experiemental gradient of nutrient enrichment. Aquatic Botany. 78: 103-117.

Kendrick, G. A. and D. I. Walker. 1991. Dispersal distances of Sargassum spinuligerum (Sargassaceae, Phaeophyta) measured directly by vital staining and venturisuction sampling. Mar. Ecol. Prog. Ser. 79: 133-138.

Kuffner, I. B. and V. J. Paul. 2001. Effects of nitrate, phosphate and iron on the growth of macroalgae and benthic cyanobacteria form Cocos Lagoon, Guam. Mar. Ecol. Prog. Ser. 222: $63-72$. 
Lang, C. J., K. W. Marks, P. A. Kramer, P. R. Kramer and R. N. Ginsburg. 2010. AGRRA protocols version 5.4. In: http://www.agrra.org/method/AGRRA-V5.4_2010.

Lang, J. and R. N. Ginsburg. 2006. A vision for regular, rapid assessments of the tropical northwestern Atlantic's coral reefs. Rev. Biol. Trop. 54 (3): 23-29.

Lapointe, B. E., F. X. Niell and J. M. Fuentes. 1981. Community structure, succession, and production of seaweeds associated with mussel-rafts in the Ria de Arosa, N. W. Spain. Mar. Ecol. Prog. Ser. 5: 243-251.

Lapointe, B. E., M. M. Littler and D. S. Littler. 1993. Modification of benthic community structure by natural eutrophication: the Belize Barrier Reef. Proceeding of the seventh International Coral Reefs Symposium, Guam. 1: 323-334.

Lapointe, B. E., M. M. Littler and D. S. Littler. 1997. Macroalgal overgrowth of fringing coral reefs at discovery bay, Jamaica: Bottom-up versus Top-down control. Proc $8^{\text {th }}$ Int. Coral Reef Sym 1:927-932.

Lapointe, B. E., P. J. Barile and W. R. Matzie. 2004. Anthropogenic nutrient enrichment of seagrass and coral reef communities in the Lower Florida Keys: discrimination of local versus regional nitrogen. Journal of experimental marine biology and ecology. 308:23-58.

Lapointe, B. E., P. J. Barile, M. M. Littler and D. S. Littler. 2005. Macroalgal blooms on southeast Florida coral reefs II. Cross-shelf discrimination of nitrogen sources indicates widespread assimilation of sewage nitrogen. Harmful Algae. 4: 1106-1122.

Lapointe, B. E., R. Langton, B. J. Bedford, A. C. Potts, O. Day and C. Hu. 2010. Land-based nutrient enrichment of the Buccoo Reef Complex and fringing coral reefs of Tobago, West Indies. Marine Pollution Bulletin. 60: 334-343.

Larned, S. T. 1998. Nitrogen versus phosphorus limited growth and sources of nutrients for coral reef macroalgae. Marine Biology. 132: 409-421.

Lewis, S. M. 1986. The role of herbivorous fishes in the organization of the Caribean reef community. Ecol. Monogr. 56 (3): 183-200.

Lewis, S. M. 1986. The role of herbivorous fishes in the organization of the Caribean reef community. Ecol. Monogr. 56 (3): 183-200.

Lirman, D. and P. Biber. 2000. Seasonal dynamics of macroalgal communities of the Northern Florida Reef Track. Botanica Marina. 43: 305-314.

Littler, D. S. and M. M. Littler. 2000. Caribbean reef plants. OffShore graphics, Inc. 542 pp. 
Littler, M. M. and D. S. Littler. 1980. The evolution of thallus form and survival strategies in benthic Marine Macroalgae: Field and Laboratory tests of a functional form model. 116 (1): 25-44.

Littler, M. M., D. S. Littler and B. E. Lapointe. 1993. Modification of tropical reef community structure due to cultural eutrophication: the southwest coast of Martinique. Proceeding of the Seventh International Coral Reefs Symposium, Guam. 1: 335-343.

Littler, M. M., D. S. Littler, B. L. Brooks and B. E. Lapointe. 2006. Nutrient manipulation methods for coral reef studies: A critical review and experimental field data. Journal of Experimental Marine Biology and Ecology. 336: 242-253.

Littler, M. M., D. S. Littler, B. L. Brooks. 2010. The effects of nitrogen and phosphorus enrichment on algal community development: Artifical mini-reefs on the Belize Barrier Reef sedimentary lagoon. Harmful Algae. 9: 255-263.

Lobel, P. S. and J. C. Ogden. 1981. Foraging by the herbivorous parrotfish Sparisoma radians. Marine Biology. 64: 173-183.

Lotze, H. K., B. Worm and U. Sommer. 2000. Propagule banks, herbivory and nutrient supply control population development and dominance patterns in macroalgal blooms. Oikos. 89: 46-58.

Lüning, K. 1990. Seaweeds. Their environment, biogeography and ecophysiology. Yarish, C. and H. Kirkam (eds). A wiley-Interscience publication. U.S: 527 pp.

McClanahan, T. R. 1997. Primary succession of coral reef algae: differing patterns on fished versus unfished reefs. Journal of experimental marine biology and ecology. 218: 77-102.

McClanahan, T. R., E. Sala, P. J. Mummby and S. Jones. 2004. Phosphorus and nitrogen enrichment do not enhance brown frondose "macroalgae'. Marine Pollution Bulletin. 48: 196-199.

Moore, R., W.D. Clark and D. S. Vodopich. 1998. Population dynamics and community: In Botany, $2^{\text {nd }}$ Edition. McGraw-Hill Companies, Inc: 919 pp.

Mumby, P. J. and R. S. Steneck. 2008. Coral reef management and conservation in light of rapidly evolving ecological paradigms. Trends in Ecology and Evolution. 23 (10): 555563.

Nemeth, R. S., L. D. Whaylen and C. V. Pattengill-semmens. 2003. A rapid assessment of coral reefs in the Virgin Islands (Part 2: Fishes). Atoll. Res. Bull 496: 566-589.

Pedersen, M. F. and J. Borum. 1997. Nutrient control of estuarine macroalgae: growth strategy and the balance beween nitrogen requirements and uptake. Mar. Ecol. Prog. Ser. 161: 155-163. 
Poore, A. G. B., A. H. Campbell, R. A. Coleman, G. J. Edgar, V. Jormalainen, P. L. Reynolds, E. E. Sotka, J. J. Stachowicz, R. B. Taylor, M. A. Vanderklift and E. Duffy. 2012. Global patterns in the impact of marine herbivores on benthic primary producers. Ecology Letters. 15: 912-922.

Rasher, D. R., S. Engel, V. Bonito, G. J. Fraser, J. P. Montoya and M. E. Hay. 2012. Effects of herbivory, nutrients, and reef protection on algal proliferation and coral growth on a tropical reef. Oecologia. 169: 187-198.

Reed, D. C., S. C. Schoroeter and P. T. Raimondi. 2004. Spore supply and habitat availability as sources of recruitment limitation in the giant kelp Macrocystis pyrifera (Phaeophyceae). J. Phycol. 40: 275-284.

Reef, R., J. M. Pandolfi and C. E. Lovelock. 2012. The effect of nutrient enrichment on the growth, nucleic acid concentrations and elemental stoichiometry of coral reef macroalgae. Ecology and Evolution. 2 (8): 1985-1995.

Ritson-Williams, R., S. N. Arnold, N. D. Fogarty, R. S. Steneck, M. J. A. Vermeij and V. Paul. 2009. New perspectives on ecological mechanisms affecting coral recruitment on reefs. Smithsonian contributions to the marine science. 38: 437-457.

Ruiz, H. and D. L. Ballantine. 2009. Dynamics of the shelf edge coral reef-associated macroalgae at La Parguera, Puerto Rico. Caribbean journal of science. 45 (2-3): 260-268.

Sammarco, P. W. 1983. Effects of fish grazing and damselfish territoriality on coral reef algae. I. Algal community structure. Mar. Ecol. Prog. Ser. 13: 1-14.

Smith, J. E., J. W. Runcie and C. M. Smith. 2005. Characterization of a large-scale ephemeral bloom of the green alga Cladophora sericea on coral reefs of West Maui, Hawai. Mar. Ecol. Prog. Ser. 302: 77-91.

Smith, J., C. Hunter and C. Smith. 2010. The effects of top-down versus bottom-up control on benthic coral reef community structure. Oecologia 163:497-507.

Smith, T. B. 2008. Temperature effects on herbivory for an Indo-Pacific parrotfish in Panama: implications for coral-algal competition. Coral Reefs. 27: 397-405.

Sotka, E. E. and M. E. Hay. 2009. Effects of herbivores, nutrient enrichment, and their interactions on macroalgal proliferation and coral growth. Coral Reefs. 28:555-568.

Steneck, R. S. and M. N. Dethier. 1994. A functional group approach to the structure of algaldominated communities. Oikos. 69: 476-498. 
Stiger, V. and C. E. Payri. 1999. Spatial and temporal patterns of settlement of the brown macroalgae Turbinaria turbinata and Sargassum mangarevense in a coral reef on Tahiti. Mar. Ecol. Prog. Ser. 191:91-100.

Szmant, A. M. 2002. Nutrient enrichment on coral reefs: is it a major cause of coral reef decline? Esruaries. 25: 743-766.

Thacker, R. W., D. W. Ginsburg and V. J. Paul. 2001. Effects of herbivores exclusion and nutrient enrichment on coral reef macroalgae and cyanobacteria. Coral Reefs. 19: 318329.

Tsai, C-C., J-S. Chang, F. Sheu, Y-T. Shyu, A. Yi-Chuan, S-L. Wong, C-F. Dai and T-S. Lee. 2005. Seasonal growth dynamics of Laurencia papillosa and Gracilaria coronifolia from a highly eutrophic reef in southern Taiwan: temperature limitation and nutrient availability. Journal of experimental marine biology and ecology. 315: 49-69.

Vance, R. R. 1988. Ecological succession and the climax community on a marine subtidal rock wall. Mar. Ecol. Prog. Ser. 48: 125-136.

Walsh, S. M. 2011. Ecosystem-scale effects of nutrients and fishing on coral reefs. Journal of marine biology. doi: 10.1155/2011/187248: 13 .

Worm, B. and H. K. Lotze. 2006. Effects of eutrophication, grazing, and algal blooms on rockery shores. Limnol. Oceanogr. 51 (1, part 2): 569-579.

Worm, B., H. K. Lotze and U. Sommer. 2001. Algal propagule banks modify competition, consumer and resource control on Baltic rocky shores. Oecologia. 128: 281-293.

Worm, B., H. K. Lotze, C. Bostrom, R. Engkvist, V. Labanauskas, U. Sommer. 1999. Marine diversity shift linked to interactions among grazers, nutrients and propagules banks. Mar. Ecol. Prog. Ser. 185: 309-314.

Zhang, Q. S., Y. Z. Tang, S. K. Liu, S. B. Zhang, Z. C. Lu. S. H. Cu and Y. Q. Yu. 2012. Zygote-derive seedling production of Sargassum thurbergii: focus on two frequently experienced constraints in tank culture of seaweed. J. Appl. Phycol. 24:707-714. 


\section{CHAPTER 3 - CONCLUSIONS, IMPLICATIONS AND FUTURE DIRECTIONS}

Results of present study showed that nutrient loading and herbivory pressure significantly affect abundance of early-successional species while late-successional species are primarily controlled by herbivory and secondarily by nutrient availability. Thus, it is reinforced the importance of preventing overfishing of coral reef herbivorous fish since they are capable of controlling macroalgal assemblages in all successional stages, early and late stages. Indeed, several authors have reported that reduction of herbivores as a consequence of harvesting could seriously reduce coral reef resilience (Hughes et al., 2010; Mumby and Steneck, 2008). Additionally, assuming the role of adult macroalgal assemblages as potential propagule supply, coral reef herbivorous fishes could exert an indirect effect on controlling macroalgal by limiting abundance of adults and consequently production of new propagules. In contrast, the impact of nutrient loading was found significant only on early-successional species of coral reef macroalgal (e.g., filamentous algae such as Chaetomorpha sp., and Ceramium sp.) while decreasing in magnitude towards late-successional species (Sargassum sp., and Turbinaria sp.). In the case of calcareous articulated algae, nutrient significantly raised abundance but only in absent or reduction of herbivorous fish.

Grazing pressure as primary ecological driver and nutrient availability as secondary ecological driver have been also found in several recent coral reef studies (Burkepile and Hay, 2009; Sotka and Hay, 2009; Ferrari et al., 2012; Poore et al., 2012). However, the magnitude impact of each driver on macroalgae species could vary depending upon herbivore density and concentration of nutrients. Smith et al. (2005) reported overgrowth of Cladophora sericea in Hawaiian coral reef caused by eutrophication where grazing pressure, sea-urchin and fish included, was not sufficient to control it. Thus, future coral reef studies could address the 
following questions: 1) what density and biomass of herbivorous fish and invertebrates are required to control macroalgal overgrowth at different levels of nutrient availability? and 2) what density and biomass of coral reef macroalgae can herbivores control? For instance, Hoey and Bellwood (2011) reported a decrease of reef fish grazing rate as macroalgae density increase. In addition, because the most studied nutrients on coral reef macroalgae, nitrogen and phosphorous, could exert different effects on growth rate and production of chemical deterrent compounds of algae, also affecting grazing rate and herbivorous preferences (Larned, 1998, Boyer et al., 2004; Rasher and Hay, 2010; Hay et al., 2011) an upcoming scientific research could investigate: 2) How concentration and availability, of different nutrients (e.g., nitrogen and/or phosphorous) found on coral reef common pollution sources would affect grazing rate and consumption preferences of herbivores? In this sense, some secondary metabolites have been described as chemical defense of algae (e.g., Sargassum sp.) against different herbivore groups (Duffy and Hay, 1994) which concentration could increase with nutrient addition (Hay et al., 2011). In contrast, Boyer et al. (2004) reported an increase of herbivory rates as a consequence of higher nutrient content in Acanthophora sp. Perhaps, because of above mentioned studies analyzed different macroalgae species, opposite responses to nutrient enrichment treatment of macroalgae resistance and tolerance to herbivory were found. Furthermore, macroalgal species could response differently to nutrient enrichment depending on type and concentration of nutrient available which could also affect herbivory rate.

As a result of high macroalgal diversity and difficulties of "in situ" species identification, the classification system at form-functional groups, following Steneck and Dethier (1994), was used in the current study. As a first approach to characterize macroalgal assemblages, analysis of form-functional groups provides useful results, but it limits the possibility of examining 
important macroalgal elements such species-specific chemical defenses, interspecific competition and herbivores preferences (Padilla and Allen, 2000). For instance, Dictyota spp. are known to chemically deter herbivores while benefiting not only the individual plant but also associated macroalgae species (Pereira et al., 2010). Therefore, it would be convenient to use a survey method where form-functional group and genus or species composition are combined as possible, at least for most common species. In addition, conclusions emerging from present research referred to impact and magnitude of coral reef drivers as well as successional patterns are based on a single abundance metric, percent cover of macroalgae. However, grazing intensity could change depending upon density and height within macroalgal individuals of same species (Hoey, 2010; Hoey and Bellwood, 2011). Additionally, in particular macroalgal species of earlysuccessional stages could take advantages of nutrient availability and not only cover larger areas but also increase growth rate which could be tested by using wet and dry mass as metric (Dailer et al., 2012). Thus, in order to have a more truthful effect of coral reef macroalgal community ecological drivers, other metrics such as biomass and plant height and /or complexity index, or architectural index should be included.

Crustose algae (e.g., Peyssonnelia spp. and Hydrolithon spp. and Porolithon spp.) showed about $14 \%$ cover in recruitment tiles and approximately $4 \%$ and $8 \%$ onto permanent tiles and field established communities respectively. However, the experimental time of present study was nine months which, for this particular group of algae, could be short in order to observe long-term response to ecological drivers. For instance, in field caged experiments Burkepile and Hay (2009) reported abundance of crustose algae of nearly $15 \%$ after 22 weeks $\left(5^{\text {th }}\right.$ month of first year), and approximately $20 \%$ after 27 weeks $\left(6^{\text {th }}\right.$ month of second year). However, crustose algae could cover up to $60 \%$ after a year of having placed experimental tiles on well protected 
coral reefs (McClanahan, 1997). Nonetheless, the fact that coral reef herbivorous fish are able not only to strongly control fleshy macroalgae but also promote crustose algae cover has important implications for coral reef resilience. Indeed, Vermeij and Smith (2011) showed how crustose coralline algae could induce coral recruitment whereas it is well known the negative impact of fleshy macroalgal abundance on recruitment and juvenile survival rate of corals (Kuffner et al., 2006; Box and Mumby, 2007). Thus, after natural disturbance such as hurricane damages and coral bleaching events, success of coral recruitment and juvenile survival rate are key processes for coral cover recover and consequently coral reef resilience. Both mentioned process are directly impacted by herbivory pressure as it reduce fleshy macroalgal abundance while promoting crustose algae (Mumby and Steneck, 2008; Diaz-Pulido et al., 2009). Although, it is recommended for future field researches to extend the study period longer than a year and if possible analyze crustose algae at lower taxonomic levels, genus or species. Also, not only fish but other coral reef herbivores such as snails, crabs and urchins should be included since they could exert significant impact on early successional species and thus contribute to control macroalgae growth (Steneck, 1983; O’leary and McClanahan, 2010; Butler and Mojica, 2012).

\section{References}

Box, S. J. and P. J. Mumby. 2007. Effect of macroalgal competition on growth and survival of juvenile Caribbean corals. Mar. Ecol. Prog. Ser. 342: 139-149.

Boyer, K. E., P. Fong, A. R. Armitage and R. A. Cohen. 2004. Elevated nutrient content of tropical macroalgae increases rates of herbivory in coral, seagrass, and mangrove habitats. Coral Reefs. 23: 530-538.

Butler, M. J. and A. M. Mojica. 2012. Herbivory by the Caribbean king crab on coral patch reefs. Mar. Biol. 159: 2697-2706.

Burkepile, D. E and M. E. Hay. 2009. Nutrient versus herbivore control of macroalgal community development and coral growth on a Caribbean reef. Mar. Ecol. Prog. Ser. 389: 71-84. 
Dailer, M. L., J. E. Smith and C. M. Smith. 2012. Responses of blooms forming and non-blloms forming macroalgae to nutrients enrichment in Hawai'i, USA. Harmful algae. 17: 111125.

Diaz-Pullido, G., L. J. McCook, S. Dove, R. Berkelmans, G. Roff, D. I. Kline, S. Weekds, D. H. Williamson and O. Hoegh-Guldberg. 2009. Doom and boom on a resilient reef: Climate change, algal growth and coral recovery. PLoS ONE 4(4): e5239. doi:10.1371/journal.pone.0005239.

Duffy, J. E. and M. E. Hay. 1994. Herbivore resistant to seaweed chemical defense: the roles of mobility and predation risk. Ecology. 75 (5): 1304-1319.

Ferrari, R.; M. Gonzalez-Rivero; J. C. Ortiz and P. Mumby. 2012. Interaction of herbivory and seasonality on the dynamic of Caribbean macroalgae. Coral Reefs. 31 (3): 683-692.

Hay, K. B., A. G. B. Poore and C. E. Lovelock. 2011. The effects of nutrient availability on the tolerance to herbivory in a brown seaweed. Journal of ecology. 99: 1540-1550.

Hoey, A. S. 2010. Size matters: macroalgal height influences the feeding response of coral reef herbivores. Mar. Ecol. Prog. Ser. 411: 299-302.

Hoey, A. S. and D. R. Bellwood. 2011. Suppresion of herbivory by macroalgal density: a critical feedback on coral reef? Ecology letters. 14: 267-273.

Hughes, T. P., N. A. J. Graham, J. B. C. Jackson, P. Mumby and R. S. Steneck. 2010. Rising to the challenge of sustaining coral reef resilience. Trends in ecology and evolution: 25(11): 633-641.

Kuffner, I. B., L. J. Walters, M. A. Becerro, V. J. Paul, R. Ritson-Williams and K. S. Beach. 2006. Inhibition of coral recruitment by macroalgae and cyanobacteria. Mar. Ecol. Prog. Ser. 323: 107-117.

Larned, S. T. 1998. Nitrogen versus phosphorus limited growth and sources of nutrients for coral reef macroalgae. Marine Biology. 132: 409-421.

McClanahan, T. R. 1997. Primary succession of coral reef algae: differing patterns on fished versus unfished reefs. Journal of experimental marine biology and ecology. 218: 77-102.

Mumby, P. J. and R. S. Steneck. 2008. Coral reef management and conservation in light of rapidly evolving ecological paradigms. Trends in Ecology and Evolution. 23 (10): 555563.

O'Leary, J. K. and T. R. McClanahan. 2010. Trophic cascade results in large-scale coralline algae loss through differential grazer effects. Ecology. 12: 3584 - 3597. 
Padilla, D. K. and B. J. Allen. 2000. Paradigm lost: reconsidering functional form and group hypotheses in marine ecology. Journal of experimental marine biology and ecology. 250: 207-221.

Pereira, R. C.; E. M. Bianco; L. B. Bueno; M. A. L. de Oliveira, O. S. Pamplona and B. A. P. da Gama. 2010. Associational defense against herbivory between Brown seaweeds. Phycologia. 49 (5): 424-428.

Poore, A. G. B., A. H. Campbell, R. A. Coleman, G. J. Edgar, V. Jormalainen, P. L. Reynolds, E. E. Sotka, J. J. Stachowicz, R. B. Taylor, M. A. Vanderklift and E. Duffy. 2012. Global patterns in the impact of marine herbivores on benthic primary producers. Ecology Letters. 15: 912-922.

Rasher, D. B. and M. E. Hay. 2010. Seaweed allelophaty degrades the resilience and function of coral reefs. Communicative and Integrative Biology. 3 (6): 564-566.

Smith, J. E., J. W. Runcie and C. M. Smith. 2005. Characterization of a large-scale ephemeral bloom of the green alga Cladophora sericea on coral reefs of West Maui, Hawai. Mar. Ecol. Prog. Ser. 302: 77-91.

Sotka, E. E. and M. E. Hay. 2009. Effects of herbivores, nutrient enrichment, and their interactions on macroalgal proliferation and coral growth. Coral Reefs. 28:555-568.

Steneck, R. S. 1983. Quantifying herbivory on coral reefs: Just scratching the surface and still biting off more than we can chew. In "The ecology of deep and shallow coral reefs". L. Reaka (ed.), Simposia Series for Undersea Reserarch, NOAA'S Undersea Research Program. 1(1): 103-111.

Steneck, R. S. and M. N. Dethier. 1994. A functional group approach to the structure of algaldominated communities. Oikos. 69: 476-498.

Vermeij, M. J. A., M. L. Dailer and C. M. Smith. 2011. Crustose coralline algae can suppress macroalgal growth and recruitment on Hawaiian coral reefs. Mar. Ecol. Prog. Ser. 422: $1-7$. 
Appendix 1. List of algal species identified for the study site and assigned form functional groups (FFG) following Steneck and Dethier, 1994 classification

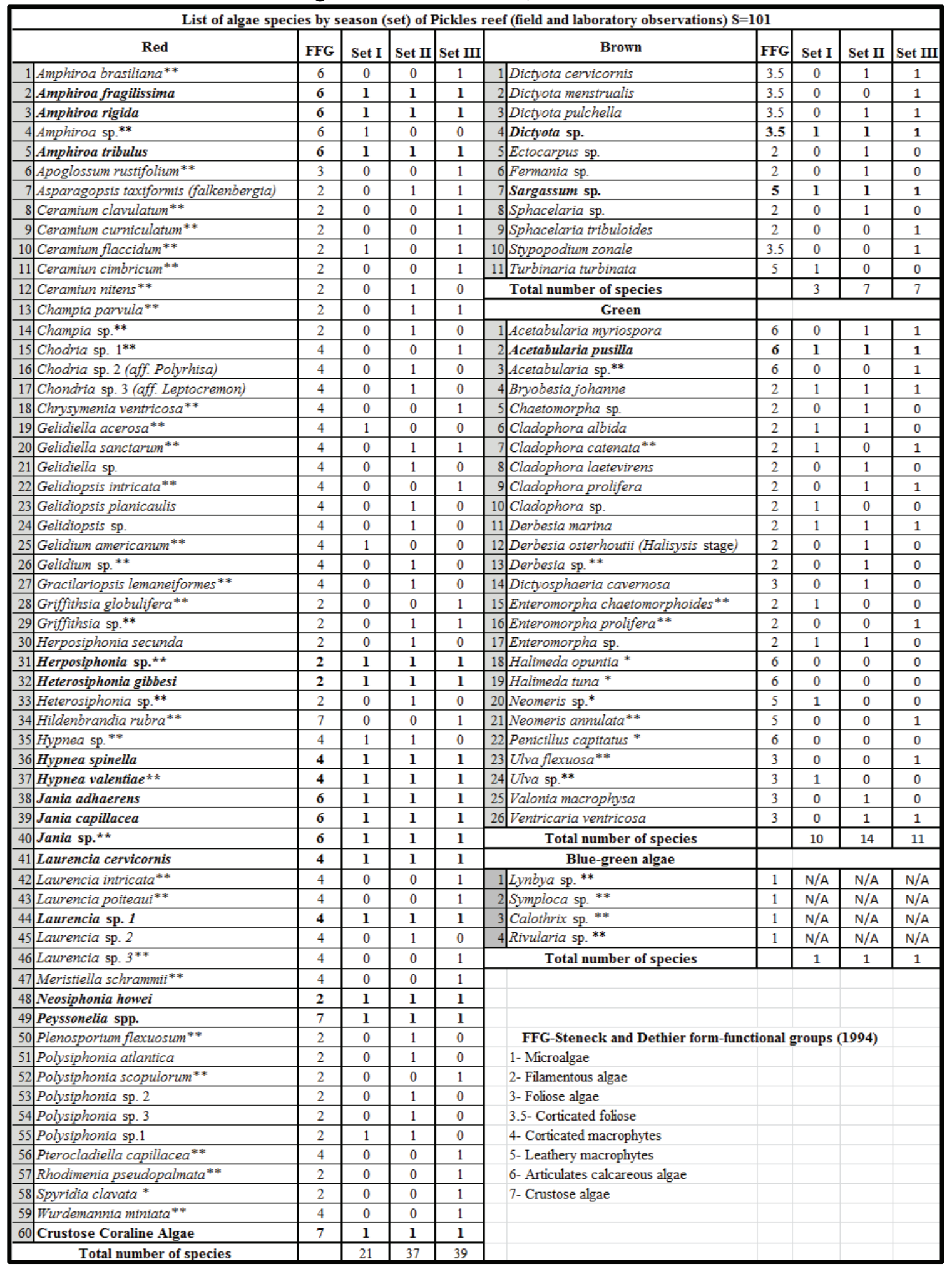

